\title{
Irreducible Plurality, Indivisible Unity: Singapore Relational Constitutionalism and Cultivating Harmony Through Constructing a Constitutional Civil Religion
}

\author{
Li-ann Thio* ${ }^{*}$
}

(Received 18 August 2019; accepted 29 August 2019)

\begin{abstract}
This Article seeks to explore the nature, function, source, and content of a constitutional civil religion (CCR) within Singapore's constitutional experiment in managing the diversity of race and religion and promoting solidarity. CCR is constructed as a strategy to secure social harmony within the world's most religiously diverse polity, through recognizing an irreducible plurality in ethnic and religious terms, while maintaining an indivisible unity through nurturing bonds of citizen solidarity. This dovetails with the function of the constitution as an instrument of social integration, involving the articulation and regular affirmation of shared community values and aspirations, as well as process and practices—or public rituals—which regulate dispute resolution or conflict management during instances or crises where racial and religious harmony is threatened. A functional approach is taken towards the idea of a civil religion, and the tasks of integration, legitimation, and inspiration it may play within a constitutional order. The nature of civil religion in general, and the sources of CCR in Singapore, as well as its expression as a public ritual in managing religious disharmony disputes is discussed.
\end{abstract}

Keywords: Religious freedom; religious diversity; religious harmony; constitutional identity; civil religion; conflict resolution; public rituals; soft law; Singapore constitutionalism

\section{A. Introduction}

Since independence on August 9, 1965, the $\operatorname{accidental}^{1}$ nation of Singapore has struggled with the fissiparous tendencies ethnic, religious, and linguistic diversity pose. Its incorporation into the Malaysian Federation from 1963-1965 failed as Malay elites considered Singapore-where $70 \%$ of the population is Chinese ${ }^{2}$ - a "stooge for communist China." 3

The Singapore political leadership's vision of a "Malaysian Malaysia" based on civic nationalism was rejected by the UMNO ruling party's agenda of a "Malay Malaysia;" under this, bumiputeras-Malays and other indigenous peoples_enjoyed preferential rights and affirmative privileges, Malays were politically dominant, Islam was the Federation's constitutionally

${ }^{\star}$ Ph.D. (Cantab); LL.M. (Harvard); B.A. Jurisprudence (Oxford); Barrister (G.I.), Provost Chair Professor, Faculty of Law, National University of Singapore.

${ }^{1}$ Sajjad Ashraf, A Tale of Two Accidental Nations, STRAits Times (Aug. 3, 2015), https://www.straitstimes.com/opinion/atale-of-two-accidental-nations.

${ }^{2}$ As of 2015 , the ethnic composition of the population was Chinese (74.3\%), Malay (13.3\%), and Indian (9.1\%). The remaining 3.2\% are Eurasians and other communities. Singapore at a Glance, NAT'L INTEGRATION CounCIL, (July 20, 2019, 3:49 PM), https://www.nationalintegrationcouncil.org.sg/living-in-singapore/singapore-at-a-glance.

${ }^{3}$ Prime Minister (PM) Lee Hsien Loong, Race, Multiracialism and Singapore's Place in the World, STRAITS TIMES (Sept. 30, 2017), https://www.straitstimes.com/opinion/race-multiculturalism-and-singapores-place-in-the-world [hereinafter Race].

(c) The Author(s) 2019. Published by Cambridge University Press on behalf of the German Law Journal. This is an Open Access article, distributed under the terms of the Creative Commons Attribution licence (https://creativecommons.org/licenses/by/4.0/), which permits unrestricted re-use, distribution, and reproduction in any medium, provided the original work is properly cited. 
recognized official religion, ${ }^{4}$ and non-Malays were treated as lodgers-orang tumpangan. ${ }^{5}$ This Malay-Muslim nationalism continues to trouble Malaysian political and judicial discourse.

Aversive constitutionalism was evident in Singapore's departure from the Malaysian approach towards questions of race and religion. The Singapore leadership recognized a uni-national state was one doomed for destruction; majoritarian ethnic chauvinism was rejected ${ }^{6}$ as a multi-racial secular society was a dire necessity to ensure state survivability. ${ }^{7}$ To this end, two extreme government models were rejected. First, a theocratic state which fused political and religious authority, where religious preferentialism exposes religious minorities to unequal treatment. Second, a politically totalitarian state such as communism, which eviscerates civil and religious freedoms.

The Singapore constitution was not a product of a constituent assembly or protracted negotiations with colonial powers. Early plans to draft a new constitution were scuttled. ${ }^{8}$ Singapore's existing state Constitution was retained and modified to befit the status of independent statehood. Nonetheless, the principle of multi-racialism and secular democracy was affirmed in the report of the constitutional commission convened in 1966 to propose adequate constitutional safeguards to secure the rights of racial, linguistic, and religious minorities. ${ }^{9}$ The constitution guarantees religious freedom under Article 15 while not identifying with any religion; Article 153 provides for some religious group autonomy and legal pluralism ${ }^{10}$ through the Administration of Muslim Law Act (AMLA). This establishes an Islamic religious council (MUIS), syariah courts, and authorizes the application of religious law to a limited range of personal and customary law matters. AMLA "reassures the Muslim community that its religion, Islam, and their Muslim way of life, have their rightful place in plural Singapore."11

While the fundamental liberties chapter contains no minority rights, Article 152 provides for minority protective duties. The constitution establishes the Group Representation Constituency and Presidential Council for Minority Rights, which guarantees legislative minority representation and provides for some legislative oversight respectively. ${ }^{12}$ In 2016, a constitutional commission was convened to recommend amendments to the presidency, including ensuring all races were represented in the office of the head of state $^{13}$ through a non-quota method. ${ }^{14}$ The symbolic

\footnotetext{
${ }^{4}$ Federal Const. of Malaysia, arts. 3, 12, 10 (1957).
}

${ }^{5}$ Transcript, Minister Mentor Lee Kuan Yew's Interview with Seth Mydans of New York Times \& Iht on 1 September 2010, Prime MinISTER's OfFICE SINGAPORE (Sept. 1, 2010), https://www.pmo.gov.sg/newsroom/transcript-minister-mentor-leekuan-yew $\%$ E2\%80\%99s-interview-seth-mydans-new-york-times-iht-1.

${ }^{6}$ Equal citizenship is sought through measures taken to guard against majoritarianism of the Chinese who compose $74 \%$ of the population. This includes ensuring equal opportunities regardless of race or religion, guaranteeing religious freedom, and clamping down on hate speech. Nur Asyiqin Mohamad Salleh, Singapore Must Safeguard Position of Minorities Amid Growing Polarization Abroad: Shanmugam, STRAITS TIMES (Feb. 1, 2017) https://www.straitstimes.com/singapore/singapore-mustsafeguard-position-of-minorities-amid-growing-polarization-abroad-shanmugam.

${ }^{7}$ Eddie Barker, Minister for Law and National Development, Appointment of Constitution Commission, 24 SINGAPORE PARLIAMENT Reports (SPR), at col. 429 (Dec. 22, 1965).

${ }^{8}$ A Team of Experts to Draft S’pore Charter, STRAITs TIMES, at 20 (Sept. 11, 1965), available at http://eresources.nlb.gov.sg/ newspapers/Digitised/Article/straitstimes19650911-1.2.154?ST=1\&AT=search\&k=A\%20Team\%20of\%20experts\%20to\% $20 \mathrm{draft} \% 20$ \% 27 pore\%20Charter\&QT=a,team,of,experts,to,draft,spore,charter\&oref=article.

${ }^{9}$ Li-ann Thio, The Passage of a Generation: Revisiting the 1966 Constitutional Commission, in The Evolution Of A Revolution: 40 Years Of The Singapore Constitution 7-49 (Li-ann Thio \& Kevin YL Tan eds., 2009).

${ }^{10}$ Vineeta Sinha, Religion-State Encounters In Hindu Domains: From The Straits Settlement To Singapore (Springer Asia Series 1, 2011); Gary F. Bell, Religious Legal Pluralism Revisited: The Status of the Roman Catholic Church and Her Canon Law in Singapore, 7 ASIAN J. COMP. L. 5 (2012).

${ }^{11}$ Zainul Abidin Rasheed, Senior Minister of State (Foreign Affairs), Administration of Muslim Law (Amendment) Bill, 85 SPR, at col. 741 (Nov. 17, 2008).

${ }^{12}$ Const. OF THE Republic OF Singapore arts. 39(A), 68, 152 (1965).

${ }^{13}$ Supra note 3. PM Lee Hsien Loong noted that having multiracial presidents was symbolically important, reminding all, "especially the Chinese majority race," that every community had a role.

${ }^{14}$ See Const. of THE Republic of Singapore art. 19(B) (reserving elections for a community that has not held the presidency for five or more consecutive terms). 
importance of multi-racialism was reiterated as "fundamental to Singapore's cohesion and survival." 15

First Prime Minister (PM) Lee Kuan Yew hoped that Singapore's individualist equal rights approach "not based on the concepts of exclusiveness of race, language, religion" would assist her neighbors "in reaching similar rational adjustments in their own domestic arrangements" regarding "problems of language and culture." 16 Clearly, matters of ethnicity and religion are viewed as belonging to the realm of emotions, "the primordial pulls of ancestry, race, language and religion." 17 To distance the polity from such passions, a rational, technocratic, and pragmatic approach towards governance was adopted. In return for living in a disciplined, secure, economically thriving state, the people tolerated the frequently paternalistic style of government.

The lack of affect or emotion, however, could not nurture a sense of solidarity; the bureaucratic view of state-citizen relations was largely transactional, not covenantal. This is reflected in statements made by a defense ministry official before a court that the refusal of Jehovah's Witnesses to perform military service meant they enjoyed the socio-economic benefits of citizenship without supporting "the very social and political institutions and structure which enable them to do so." 18

The Singapore constitutional text is terse, filled with technical provisions unendearing to the layman. ${ }^{19}$ It lacks a preambular historical narrative and explicit vision of justice. It contains little to inspire affect or a sense of political belonging, being an instrument for legal technicians, not lay citizens; it provides too thin a gruel to sustain a localized communitarian version of a Habermasian constitutional patriotism. ${ }^{20}$

In Germany, having shared commitments to liberal constitutional ideals was considered antidotal to traditional nationalism. Constitutional patriotism "promises a form of solidarity distinct from both nationalism and cosmopolitanism." ${ }^{21}$ It rejects the idea of the volkstum popularized in the 1930s, under which individuals of an ethnic group were considered members of an organic community united by blood, language, and customs, which justified militaristic expansionism. Building political attachment based on constitutional values rather than tribal affiliation within polities having no shared historical past, faith, or tongue is a strategy for attaining solidarity in diversity. Rather than self-evident truths or received tradition, commonality must be constructed.

Normative aspirations and rejecting a racially homogenous state is evident in the broader Singapore constitutional order, beyond the documentary text. An expansive understanding of the concept of the Constitution is noted, encompassing not just the capital " $\mathrm{C}$ " text-and how it is judicially interpreted - and small " $\mathrm{c}$ " of constitutionally significant legislation, ${ }^{22}$ but also "soft constitutional law," ${ }^{23}$ which includes executive-authored, widely available norms and precedent setting constitutional practices and rituals which generate expectations between constitutional actors and make powerful claims on citizens. The constitution may be viewed as embodying a

\footnotetext{
${ }^{15}$ Review of Specific Aspects of the Presidency White Paper, at para. 73 (2016), available at https://www.gov.sg/ /media/ elected\%20presidency/files/white\%20paper\%20on\%20the $\% 20$ review $\% 20$ of $\% 20$ specific $\% 20$ aspects $\% 20$ of $\% 20$ the $\% 20$ elected $\%$ 20presidency.pdf.

${ }^{16}$ Lee Kuan Yew, Prime Minister, Debate on Address, Yang di Pertuan Negara, 24 SPR 14, col. 91 (Dec. 15 1965).

${ }^{17}$ Vivian Balakrishan, Foreign Affairs Minister, Budget: Committee of Supply-Head N, 94 SPR (Jan. 3, 2018).

${ }^{18}$ The High Court in Chan Hiang Leng Colin v. PP noted that Articles 128 and 131 of the Constitution do not allow a citizen to renounce his citizenship without discharging his national service obligations. 3 SLR 662, at 685 (1994).

${ }^{19}$ Article $142(3)$ provides that $50 \%$ of the net investment income of a financial year shall form part of the past reserves which must be saved, not spent. This principle of inter-generational equity is buried deep in technical provisions.

${ }^{20}$ Jan-Werner Muller, On the Origins of Constitutional Patriotism, 5 CONTEMP. POLITICAL TheORY 278 (2006). On German civil religion, see Michael Minkenberg, Civil Religion and German Unification, 20 Ger. STUD. Rev. 63 (1997).

${ }^{21}$ Jan-Werner Muller \& Kim Lane Scheppele, Constitutional Patriotism: An Introduction, 6 ICON 67 (2008).

${ }^{22}$ The "Constitution" as a concept may be understood to mean not only the written instrument that regulates government but also, "those rules that are actually applied in the governance of the State." The small "c" constitution would include laws regulating electoral processes, such as the Parliamentary Elections Act. JAN-ERIK LANE, ConstituTIONS AND POLITICAL THEORY 11 (1996).

${ }^{23}$ Li-ann Thio, Soft Constitutional Law in non-liberal Asian Constitutional Democracies, 8 ICON 766, 766-99 (2010).
} 
type of civil religion in the sense of being "an authoritative regulatory order embodying the supreme law, which seeks to promote national identity and citizen solidarity." 24 Concerns about illiberalism attending the concept of constitutional patriotism or a constitutional civil religion (CCR), which may be manipulated as an authoritarian tool of social control, in the name of religious harmony, cannot be discounted. ${ }^{25}$ This fear may be partially allayed if a minimalist thin perfectionism is adhered to-one which focuses on pacific co-existence, not coercive assimilation, where unity does not connote uniformity.

This Article explores the nature, source, content, and role of a CCR within Singapore's constitutional experiment to manage ethnic and religious diversity. This is constructed as a strategy to secure social harmony within the world's most religiously diverse polity, ${ }^{26}$ through recognizing an irreducible plurality in ethnic and religious terms while maintaining an indivisible unity through nurturing bonds of solidarity. It entails both a commitment to ethnic and religious pluralism as well as promoting conciliatory methods of dispute resolution beyond legal sanction imposed by the government or resort to judicial review. This dovetails with the integrative function of the constitution, involving regular affirmation of shared community norms and orthopraxical practices as forms of alternative dispute resolution deployed to handle racial and religious disharmony crises. A functional approach towards civil religion and the integrative, legitimating, and inspirational role it may play within a constitutional order is taken.

Part A explores the origins, nature, and typologies of the sociological phenomenon of a civil religion. It considers the utility in speaking of a Singapore CCR and how this may contribute towards solidarity. It reflects on the religious dimension of law and the need for common commitments to secure stability in plural societies. Part B examines the anatomy of this CCR, its norms, processes, rituals, and institutions. It examines how this develops and operates within Singapore's model of accommodative secularism and services relational constitutionalism which seeks to promote durable relationships and relational well-being between ethnic and religious groups. This includes expectations communicated by the government to religious groups and the harmonypromoting initiatives of religious groups. Part $\mathrm{C}$ offers concluding observations on how Singapore's CCR may contribute to securing solidarity in diversity within a non-liberal polity.

\section{B. Interrogating Civil Religion and its Relation to a Constitutional Order}

\section{Common Values and Social Stability}

Princeton theologian Max Stackhouse observed that "no complex civilization capable of including many peoples and sub-cultures within it has endured without a profound and subtle religiously oriented philosophy or theology at its core."27

\footnotetext{
${ }^{24}$ Li-ann Thio, Rule of Law, Religious Liberty and Harmony: Multiculturalism, Legal Pluralism and the Singapore Model of Accommodative Secularism, 5 J. L. RELIGION ST. 254, 257 (2017).

${ }^{25}$ See Jothie Rajah, Policing Religion, in Authoritarian Rule OF LAW 219-57 (2012) on how the Maintenance of Religious Harmony Act has been used to reinforce the state's treatment of religion as a security issue which needs to be preventatively managed by the government through the enforcement of non-justiciable restraining orders. Rajah argues that the Act, although never invoked, has been successful in socializing citizens to "perceive disparaging comments on faiths and practices as violating the precarious 'harmony' of multi-racial and multireligious Singapore," such that it has offended citizens who, through complaints, draw the state's attention to breaches of this "harmony" in seeking remedial action from the state.

${ }^{26}$ The Pew Research Center ranked Singapore first on the Religious Diversity Index in 2014:

About a third of Singapore's population is Buddhist (34\%), while $18 \%$ are Christian, $16 \%$ are religiously unaffiliated, $14 \%$ are Muslim, $5 \%$ are Hindu and $<1 \%$ are Jewish. The remainder of the population of 5 million people belongs to folk or traditional religions (2\%) or to other religions considered as a group (10\%).

Global Religious Diversity, Pew Research Center (Apr. 4, 2014), http://www.pewforum.org/2014/04/04/global-religiousdiversity/.

${ }^{27}$ Max Stackhouse, Sources of Basic Human Rights Ideas: A Christian Perspective, PEw ReSEARCH CEnTER (Sept. 24, 2018) http://www.pewforum.org/2003/01/27/sources-of-basic-human-rights-ideas-a-christian-perspective/.
} 
Except among advocates of religious theocracies, the once orthodox belief that political unity was predicated on religious unity has lost prescriptive sway. Nonetheless, the debate over religion's role in shaping national morality and its relation to democracy persists. ${ }^{28}$ Civil religion as an ersatz religion exerts a cohesive force in articulating common values or a mission; these values are sacralized, or accorded a quasi-religious authoritative quality, mediated through rituals, symbols, and ceremonies. ${ }^{29}$

Various types of civil religion exist, ${ }^{30}$ whether state-sponsored or independent, theistic, deistic, or humanist; these may be minimalist ${ }^{31}$ or utopian, in explicitly rejecting established religions, as where Robespierre sought to replace Catholicism with a Supreme Being cult in France. ${ }^{32}$ Other examples include Roman Emperor worship or pre-World War Two Japanese Shinto which venerated the Emperor's divinity. Secular, anti-religious ideologies like Russian communism had their own saints (Lenin), sacred feasts (May Day), and proselytizing belief in the global socialist revolution. ${ }^{33}$

To Coleman, civil religion operated within "the unique province of neither church nor state," 34 expressing collective conscience and communal identity. ${ }^{35}$ For Bellah, one of religion's social functions was "to provide a meaningful set of ultimate values" to base social morality upon. ${ }^{36}$ A civil religion "embodies the terms of reference in which politics will be justified," providing a kind of "overarching moral glue" in response to a "problematic pluralism" which "fragmented religious symbolism cannot provide." ${ }^{\text {" }}$

While "civil" refers to society or the political community, "religion" in this context is to be understood not as a belief in spiritual beings, ${ }^{38}$ but in the Durkheimian sense of "a unified system of beliefs and practices relative to sacred things ... things set apart and forbidden - beliefs and practices which unite into one single moral community ... all those who adhere to them." ${ }^{39}$ For Durkheim, "the cohesion and shared values fostered by religion" was essential to social order, as a healthy society depends on "affection and respect towards the collectivity fostered by religious sentiments and rituals." 40

The classic concept of civil religion has its roots in Rousseau's Social Contract (1762); ${ }^{41}$ Rousseau considered civil religion necessary to supplement the national order, even within

\footnotetext{
${ }^{28}$ George Washington—in his Farewell Address (September 19, 1796)—did not think "national morality can prevail in exclusion of religious principle." Vincent Phillip Muñoz, Religion and the Common Good: George Washington on Church and State, in THE Founders ON GOD AND GOVERnMENT 1-22 (Dreisbach et al. eds., 2004). Napoleon Bonaparte saw religion's social role in utilitarian terms. Lewis Rayapen \& Gordon Anderson, Napoleon and the Church, 66 INT. SoC. SCI. REV. 117 (1991); Sanford Kessler, On Civil Religion and Liberal Democracy, 39 J. PoliTics 119, 120 (1977).

${ }^{29}$ Alasdair MacIntyre writes of the modern nation-state presenting itself not only as a "bureaucratic supplier of goods and services," but also "a repository of sacred values" which occasionally "invites one to lay down one's life on its behalf ... it is like being asked to die for the telephone company." A Partial Response to My Critics, in AfTER MACINTYRE 303 (John P. Horton \& Susan Mendus eds. 1994).

${ }^{30}$ Robert Bellah \& Philip E. Hammond, Varieties of Civil Religion (2018) (ebook).

${ }^{31}$ The Malaysian Rukunegara is far less comprehensive than the 1789 French Declaration on the Rights of Man and Citizens, http://www.perdana.org.my/ perdana/index.php/spotlight2/item/rukun-negara-the-national-principle-of-malaysia.

${ }^{32}$ John Markoff \& Daniel Regan, The Rise and Fall of Civil Religion: Comparative Perspectives, 42 SoC. ANALYSIS 333, 346 (1981)

${ }^{33}$ John A Coleman, Civil Religion, 31 Soc. ANALYsis 67, 73 (1970).

${ }^{34} I d$. at 69.

${ }^{35}$ Jose Santiago, From "Civil Religion" to Nationalism as the Religion of Modern Times: Rethinking a Complex Relationship 48 J. Sci. Study Religion 394, 399 (2009).

${ }^{36}$ Robert Bellah, Tokugawa Religion (1957).

${ }^{37}$ Markoff \& Regan, supra note 32, at 342.

${ }^{38}$ Edward Burnett Taylor, Primitive Culture: Researches Into The Development Of Mythology, Philosophy, Religion, ARt And Custom 424 (1871).

${ }^{39}$ Emile Durkheim, The Elementary Forms of Religious Life xxxiv (Karen E. Fields trans., 1995).

${ }^{40}$ N.J. Demarath III \& Rhys H. Williams, Civil Religion in an Uncivil Society, 480 ANNALS OF THE AM. ACAD. POL. SOC. SCI. Rel. Am. Today 154, 156 (1985).

${ }^{41}$ Jean Jacque Rousseau, Of Civil Religion, in Social ConTraCt 305-06 (Ernest Barker ed., 1960).
} 
humanistic, strongly anti-clerical post-revolutionary France. While propagated by the state, civil religion was "not a distinct church but merely a statement of faith all citizens must affirm," ${ }^{2}$ to nurture patriotism and the virtuous republic. A "purely civil profession of faith" was needed to discipline society, constituting "a body of social sentiments without which no man can be either a good citizen or a faithful subject." 43 Rousseau identified a few dogmatic tenets the state was to espouse, essentially a bland form of deism, such as belief in the existence of God and the afterlife, the reward of virtue and the punishment of vice, the sanctity of the social contract and laws, and excluding religious intolerance. This ersatz religion "was to be constructed and imposed from the top down as an artificial source of civic virtue." ${ }^{4}$ The Indonesian Pancasila and Malaysian Rukunegara, statements of national ideology within Muslim-majority plural societies, represent attempts to unify a diverse population and promote broad social cooperation. ${ }^{45}$ Religiously-based civic religion attempting to connect the present with the past is found in Thailand, where Buddhist teachings as a major pillar of Thai civic religion are presented both as supporting traditional values and democratic changes. ${ }^{46}$ Attempts to revive Japanese Shintoism sought to bolster Japanese social identity and destiny. ${ }^{47}$

Other accounts of civil religion are more experience-based and bottom-up, a form of vestigial faith transmuting into a cultural tradition, ${ }^{48}$ a religion serving not otherworldly but secular ends. Popularized by Robert Bellah in the 1960s, American civil religion, ${ }^{49}$ absent an established religion, entails the nation's subordination to transcendental ethical principles not specifically identified with a sectarian religion beyond a diluted Protestantism. Its norms and rituals are found in sources such as solemn presidential statements like Lincoln's Gettysburg address, the idea of manifest destiny as God's chosen agent, and national political ceremonies like presidential inaugurations. While secular in nature, they carry sacred connotations.

Whether organic or constructed, civil religion may be seen as a project of affect, of sustaining loyalty beyond particularistic tribal identities. It resonates with the idea of constitutional patriotism, of promoting solidarity through shared constitutional norms. A civil religion to which all citizens can subscribe transcends religious nationalism. The CCR seeks to promote social integration, a precondition for collective action within a plural polity. This involves invoking what Berman terms "the religious dimension of law," 50 in the form of "legal emotions, legal passions," which is reflected in the sacred nature of the state which demands our loyalty, beyond its bureaucratic nature in promising to deliver goods and services. The former is illustrated where elected officials engage in the quasi-religious ritual of swearing an oath of office to bear "true faith and allegiance" to the Republic and to "preserve, protect and defend" the Constitution.

The Singapore CCR is a constructed one; the analysis here does not concern itself with definitional questions, but adopts a functionalist approach in terms of the role CCR has played-particularly, its ability to integrate and unify a religiously and ethnically diverse population-to nurture civil societal values and to cultivate expectations of social behavior among citizens. It considers whether it can play the priestly role of celebrating national

\footnotetext{
${ }^{42}$ Douglas H. Walker, The Tolerant Pessimist: Jean-Jacques Rousseau on Civil Religion and Religious Toleration, 7 OxFORD J. L. REL. 206, 215 (2018).

${ }^{43} \mathrm{Id}$.

${ }^{44}$ Demarath III \& Williams, supra note 40, at 156.

${ }^{45}$ Daniel Regan, Islam, Intellectuals and Civil Religion in Malaysia, 37 Soc. ANALYsis 95, 95-110 (1976) (describing Rukunegara as a "functional alternative to consociational politics of accommodations").

${ }^{46}$ Frank Reynolds, Civic Religion and National Community in Thailand, 36 J. AsIAN STUd. 267 (1977).

${ }^{47}$ K. Peter Takayama, Revitalization Movement of Modern Japanese Civil Religion, 48 Soc. ANALYSIS 328 (1988).

${ }^{48}$ The Federal Constitutional Court in Germany in the Classroom Crucifix case distinguished the influence of Christianity upon the "general cultural foundations of society" from doctrinal religious content. Claudia E. HaUpt, ReLIGION-STATE Relations in the United States and Germany 196 (2011).

${ }^{49}$ Robert N. Bellah, Civil Religion in America, 96 DAEDALUs 1 (1967).

${ }^{50}$ Harold J. Berman, Law and Logos, 44 Depaul L. Rev. 143, 158-59 (1994).
} 
ideals already achieved, as well as the prophetic ${ }^{51}$ role of calling the nation-state back to those fundamental principles animating the constitutional system, to renew the project of realizing them. ${ }^{52}$

\section{The Anatomy of Singapore Constitutional Civil Religion and its Relation to Relational Constitutionalism}

A primary imperative of a young plural nation-state is "to foster and nurture the sense of national identity," such as through "rituals and invented traditions" which "sustain the common interest of heterogeneous groups" and their belief in the legitimacy of the nation. ${ }^{53}$ Kong has demonstrated how civil religion in Singapore has explanatory force in understanding how states build national identity. This involves examining how "civic rhetoric makes use of religious symbols and the way in which civic practices resemble ritual practices." ${ }^{54}$ In the absence of shared history, unity may be nurtured by a vision of a common future.

Patriotism can be nurtured through reciting the national pledge, singing the national anthem, or national songs like "One Nation, One People, One Singapore" 55 retelling the myth of founding and commemorating great leaders and events. The nation thus is conceived as "a sacred communion of its members" who share the same values and moral faith, and who "participate in shared rituals." 56

The constitution may develop national identity through historical narratives and visions of justice. These are usually found in preambles, directive principles, fundamental duties, and bills of rights. Constitutions may also specify a national flag, anthem, language, and day, an official religion(s), and thus have a hortatory function in promoting a certain moral or spiritual ethos ${ }^{57}$ among both governors and governed; they make no pretense at liberal neutrality in imposing positive duties, such as assisting accident victims ${ }^{58}$ or requiring that the parliamentary opposition provide "constructive and responsible debate." ${ }^{\text {T9 }}$ The Singapore constitutional text has none of these features.

Two major steps are involved in the deliberate construction of a CCR: First, to articulate its content, a key tenet of which in Singapore is maintaining racial and religious harmony. Second, promoting this CCR to gain widespread acceptance and internalization and as a resource for managing crises.

\section{Setting the Context: Accommodative Secularism and Pragmatic Realism \\ 1. Religion and State}

The genesis of Singapore was found in its shock exodus from the Malaysian Federation. Early imperatives included tackling the communist threat, ethnic and religious chauvinism, and economic development. A hard-nosed pragmatism drove realist policies, such as trading with everyone.

\footnotetext{
${ }^{51}$ Martin Marty, Two Kinds of Civil Religion, in American Civil Religion 145 (Russel Richey \& Donald G Jones eds., 1974).

${ }^{52}$ Susan S. Purdy, The Civil Religion Thesis as it Applies to a Pluralistic Society: Pancasila Democracy in Indonesia (1945-1965), 36 J. INT'L AFF. 306, 307 (1982/83)

${ }^{53}$ Lily Kong, Civil Religion and the Invention of Traditions: Constructing “The Singapore Nation," 20 AustL. ReLIGIOUS STUD. REV. 77 (2007).

${ }^{54} I d$. at $78-79$.

${ }^{55}$ This was referenced as an aspirational ideal in PM Lee's 2015 National Day rally speech. Derrick Ho, National Day Rally 2015: General Election Will be Called Soon, Says PM Lee, STrAits Times (Aug. 23, 2015), https://www.straitstimes.com/ singapore/national-day-rally-2015-general-election-will-be-called-soon-says-pm-lee.

${ }^{56}$ Kong, supra note 53 , at 79.

${ }^{57}$ BHUTAN CONST. art. 9(20) (2008) (espousing "a good and compassionate society rooted in Buddhist ethos and universal human values").

${ }^{58} I d$. at art. 8(6).

${ }^{59}$ Id. at art. 18 .
} 
Singapore's religious freedom guarantees were more liberally framed at inception than the Malaysian Article 11 equivalent. Article 15 protects the rights of every person to "profess, practice and propagate" their religion; the 1966 constitutional commission explicitly rejected the Malaysian ban against religious propagation to Muslims as incompatible with secular democracy. ${ }^{60}$ The Constitution does not establish a religion ${ }^{61}$ - there is no invocatio dei. The Proclamation of Singapore of August 9, 1965-unlike the Malaysian Proclamation on Singapore $^{62}$ invoking the Muslim deity-rests on a people's "inalienable right" to be "free and independent" — an expression of popular sovereignty.

There are no apostasy laws, as Singapore's model of accommodative secularism as religious freedom "is premised on removing restrictions to one's choice of religious belief." ${ }^{3}$ "The Constitution does not have the Malaysian equivalent of defining "Malay" as someone who practices the Muslim religion-Article 160 - even if $99.4 \%$ of Malays are Muslim. The government seeks not to engage in questions of theology or religious doctrine ${ }^{64}$ and tries to be impartial between the various religions and to uphold a framework for the pacific co-existence of the many faith communities. ${ }^{65}$

A strict separationist religion-state model seeking to privatize religious faith and unjustly discount its social dimension is eschewed; citizens with religiously-shaped convictions may freely participate in democratic debate. ${ }^{66}$ The Singapore model of secularism is agnostic, not antitheistic, and secular fundamentalism associated with laik states is rejected. The degree of entanglement between religion and state exemplifies the co-operative government-religious groups partnership in promoting social welfare. ${ }^{67}$ In institutional terms, the Singapore president has a role in appointing the president of the Majlis under Section 7 AMLA. The violation of halal certification laws under Section 88(5) AMLA is a generally applicable offense, and the power of MUIS to collect fines for this offense reflects the "unique role of MUIS in a multi-racial, multi-religious society" and the government's commitment to "fostering respect for important religious practices and safeguarding the interests of minorities in Singapore." ${ }^{\text {"S }}$ Singapore practices a brand of "secularism with a soul," which is "uniquely Singaporean, our own style of racial and religious harmony," ${ }^{69}$ quite "unlike secular states in the West" and Muslim-majority Turkey. ${ }^{70}$ Here, religion is recognized as having a role "in forging a harmonious and cohesive society in our Singapore."71

In contextualizing religious practice within Singapore's unique circumstances, such as its dense population, the Muslim call to prayer-azan — through mosque loudspeakers was modified to placate non-Muslims in the vicinity. Loudspeakers were first turned inward and the government

\footnotetext{
${ }^{60}$ Report of the Constitutional Commission, para. 38 (Singapore Government Printer, 1966). See A. Padre, The Right to Choose One's Religion, Straits Times, Mar. 9, 1966, at 6. (Malay Christian priest stating it was possible to practice Malay customs without being a Muslim).

${ }^{61}$ Chan Hiang Leng Colin v. PP, 3 SLR 662, 681G (1994).

${ }^{62}$ Agreement relating to the separation of Singapore from Malaysia as an independent and sovereign State. (Kuala Lumpur, Aug. 7, 1965), https://treaties.un.org/doc/Publication/UNTS/Volume\%20563/volume-563-I-8206-English.pdf.

${ }^{63}$ Nappalli Peter Williams v. ITE, 2 SLR 569, 28 (1999). For an elaboration of how Singapore courts define religion, see Arif A. Jamal \& Daniel Wong Sheng Jie, A Tale of Two Diverse Countries: Religious Diversity in Canada and Singapore, 20 GERMAN L.J. XX, 7 (2019).

${ }^{64} \mathrm{On}$ being asked to ban $\mathrm{Al}$ Arqam literature by MUIS, the government indicated it had "no theological views on who is heretical and who is not." Certain Controls Necessary to Keep Peace, STRAITS Times, Dec. 10, 1995, at 4.

65"We hold the ring so that all groups can practise their faiths freely without colliding with one another in Singapore." Prime Minister Lee Hsien Loong, Nat'l Day Rally Speech (Aug. 19, 2009) [hereinafter NDR 2009].

${ }^{66} I d$. PM Lee noted that while government is "secular," religious groups and individuals were free to propagate teachings on moral issues.

${ }^{67}$ Thio Li-ann, The Cooperation of Religion and State in Singapore: A Compassionate Partnership in Service of Welfare, 7 ReV. FAITH \& INT'L AFF. 33, 33-45 (2009).

${ }^{68}$ Hawazi Daipi, Administration of Muslim Law (Amendment) Bill, 85 SPR, col. 751 (Nov. 17, 2008).

${ }^{69}$ Id. at col. 741 .

${ }^{70}$ Zainul Rasheed, Administration of Muslim Law (Amendment) Bill, 70 SPR, col. 1259 (Apr. 15, 1999).

${ }^{71}$ Zainul Rasheed, Budget, Ministry of Community Development, 74 SPR, col. 2220 (May 23, 2002).
} 
later allocated a dedicated radio frequency over which the azan was broadcasted. Taoists have had to stop burning giant joss sticks in open areas, confining this religious practice to temple precincts. Social cohesion rests on reciprocal understanding and sensitivity, as where non-Muslims provide halal food for their Muslim guests at events, or where workplace arrangements are made to facilitate Muslim colleagues going on Hajj. ${ }^{72}$

\section{Evolving Governance Styles: From Third World to First}

The style of Singapore governance has evolved over time and provides context for understanding how solidarity in diversity is managed.

The first Prime Minister (PM) Lee Kuan Yew ruled with an authoritarian hand, scorning populism as "leaders should be feared and not necessarily liked or loved."73 Good governance rested on the pillars of meritocracy and anti-corruption ethos, and the economy was founded on a legal system anchored in a thin conception of the rule of law which secured commercial and property interests. Strict laws curbed civil and political rights in the name of maintaining social order, considered key to attracting foreign trade and investment. Describing PM Lee as a "stern father," the second PM Goh Chok Tong likened his governance style to that of an "elder brother" tasked with persuading citizens to accept the family's "house rules." 74

In the late 1980s, PM Goh mooted the idea of having a national ideology as an aid to building national identity. In 1991, Parliament adopted the white paper on Shared Values, containing five core values, including racial and religious harmony. ${ }^{75}$ These were integral to National Education which promoted responsible citizenship; the need to preserve racial and religious harmony was inculcated through the message: "Though many races, languages, religions and cultures, we pursue one destiny." 76 Cautionary tales relating to bloody racial and religious conflicts in countries like Sri Lanka, Indonesia, and Bosnia were regularly raised in public discourse. ${ }^{77}$ It was thus imperative to build "the Singapore tribe" where "the sense of belonging to a state" would outweigh "the primordial instinct of belonging to a tribe." 78 The attempt to co-opt religion to promote moral values through a religious knowledge curriculum module in public schools introduced in the early 1980s was abandoned within a decade, as it encouraged evangelism in classrooms, precipitating tensions. Indeed, aggressive proselytization was identified as a threat to racial and religious harmony in the 1989 Maintenance of Religious Harmony white paper, ${ }^{79}$ preceding the 1990 Maintenance of Religious Harmony Act (Cap 167A) (MRHA). This Act empowers the government to pre-emptively issue non-justiciable restraining or gag orders to religious leaders and groups engaged in promoting political causes under guise of promoting religious belief or whose acts caused "feelings" 80 of hostility between different religious groups.

The seminal loss of a Group Representation Constituency to the opposition Worker's Party in the 2011 General Elections inaugurated the start of a post-deferential era, fueled by the internet, as a vehicle for communicating with and holding political leaders accountable. The third PM Lee

\footnotetext{
${ }^{72}$ Senior Minister Goh Chok Tong, MUIS International Conference on Muslims in Multicultural Societies (Mar. 5, 2010), http://www.nas.gov.sg/archivesonline/speeches/view-html?filename=20100721003.htm.

${ }^{73}$ Joseph Liow, Lee Kuan Yew: The Man and His Dream, StRAits Times (Apr. 4, 2015), https://www.straitstimes.com/ singapore/lee-kuan-yew-the-man-and-his-dream.

${ }^{74}$ PM Goh on His Role as "Elder Brother," STRAiTs Times, Oct. 20, 1994, at 4.

${ }^{75}$ See Motion on Shared Values White Paper (Paper Cmd. No. 1 of 1991), 56 SPR, cols. 812-13, 818-20, 861-61, 834-36, 927, 930-31, 935, 967-68 (Jan. 14, 1991).

${ }^{76}$ Teo Chee Hean, Shared Values, 68 SPR, col. 441 (Feb. 19, 1998).

${ }^{77}$ Ong Chit Chung, Motion, Singapore 21, 70 SPR, cols. 1602, 1555 (June 5, 1999).

${ }^{78}$ PM Goh's vision: Nation Free of Racial Tribes, South China Morning Post, May 6, 1999.

${ }^{79}$ Maintenance of Religious Harmony White Paper (Cmd. 21 of 1989) (Dec. 26, 1989) [hereinafter MRHWP].

${ }^{80}$ Maintenance of Religious Harmony Act (Cap 167A), $₫ 8(1)$ [hereinafter MRHA]. For an elaboration on the prophylactic approach of the MRHA, see Kevin YL Tan \& Matthias Roßbach, State Answers to Religious Diversity in Germany and Singapore: History, Philosophy, and Strategy, 20 GERMAN L.J. XX, 19 (2019).
} 
Hsien Loong, who had urged citizens to participate more actively in public debate and life before assuming office in 2004, ${ }^{81}$ sought to usher in a culture responsive to the electorate, apologized for failures, and exhorted parliamentarians to display public servant-leadership. ${ }^{82}$ This more egalitarian bent departed from past practices where MPs were greeted in feudal fashion by lion-dances and where ministers presumed to tutor citizens to address ministers as senior partners deferentially in public debate. ${ }^{83}$ A more consultative governance style was adopted, with dialogue replacing diktat; this humbler approach yielded the reward of a near $70 \%$ of the popular vote in the 2015 general elections. ${ }^{84}$

PM Lee practices relationism in cultivating good working relationships with religious leaders, through quiet diplomacy and regular meetings, such that when a crisis erupts, "we are not dealing with strangers but with somebody we know and trust." 85 The trauma of the deadly 1960 s race riots erupting from the Prophet Muhammad procession continues to scar the national psyche, anchoring the national historical narrative of rising from the ashes of violence-producing racial and religious acrimony to religious harmony and civil peace. Celebrating some success in the project of religious harmony, PM Lee observed in 2009 that Singapore's harmonious society was "a Garden of Eden state;" but as there are snakes in every garden, he warned "if you leave ... you cannot get back in again." 86

This state of affairs requires "activist" 87 government management. PM Lee, in celebrating Singapore's golden jubilee in 2015, noted Singapore had transformed into "one united people" as "every community has progressed with the nation" in the journey "from third world to first;" this was a far cry from 1965 when minorities were "uncertain of their place in the new country," given the "fresh and raw" memories of race riots. Lee Kuan Yew's dream of a "Singaporean Singapore" had enjoyed a large measure of success, reflected symbolically in the easy interchange between government leaders and religious communities. PM Lee attended many SG50 celebrations hosted by Catholics, Protestants, Taoists, Buddhists, and Malay/Muslim organizations. Nonetheless, while "this faith, this sense of togetherness and purpose is stronger than before," he warned against taking things for granted as "we are always at risk of deep fault lines" where religiosity is growing and people are "exposed and vulnerable to extremist ideologies, like the Jihadist ideology of ISIS." 88 For example, more Singaporeans have become "self-radicalized" by online ISIS propaganda, illustrating how race and religion affect not only politics, "but also terrorism and violence." ${ }^{89}$ Multi-racialism is considered a coping strategy for dealing with the inevitable fear and anger a terrorist attack would generate, guarding against a Muslim/non-Muslim divide. The relational approach in having religious and grassroots leaders work to build stronger community ties through interactive forums and initiatives, such as "Inter-Racial and Religious Confidence Circles and SGSecure," would help Singaporeans "hold on together and let life go on as one people." 90

\footnotetext{
${ }^{81}$ Prime Minister Lee Hsien Loong, Building a Civic Society, Harvard Club of Singapore's 35th Anniversary Dinner ("People should debate issues with reason, passion and conviction, and not be passive bystanders in their own fate ....").

${ }^{82}$ Thio Li-ann, Between Apology and Apogee, Autochthony: The "Rule of Law" Beyond the Rules of Law in Singapore, SJLS 269, 284-85 (2012).

${ }^{83}$ Debate Yes, But Do Not Take on Those in Authority as "Equals," STRAit Times, Feb 20, 1995, at 11.

${ }^{84}$ Thio Li-ann, "We Are Feeling Our Way Forward, Step by Step": The Continuing Singapore Experiment in the Construction of Communitarian Constitutionalism in the 21st Century's First Decade, in Constitutionalism IN ASIA IN THE EARLY Twenty-First Century 270-94 (Albert Chen ed., 2014).

${ }^{85}$ NDR 2009, supra note 65.

${ }^{86}$ NDR 2009, supra note 65.

${ }^{87}$ Need to Guarantee Position of Minorities in Singapore, Secure Common Space: Shanmugam, STRAITs TIMES (Feb. 1, 2017), https://www.straitstimes.com/singapore/need-to-guarantee-position-of-minorites-in-singapore-secure-common-spaceshanmugam.

${ }^{88}$ Prime Minister Lee Hsien Loong, National Day Rally Speech 2015, Aug. 23, 2015.

${ }^{89}$ Prime Minister Lee Hsien Loong, supra note 3.

${ }^{90}$ Prime Minister Lee Hsien Loong, supra note 3.
} 
Two things are noteworthy. First, liberal constitutionalism is rejected insofar as it requires the state to be neutral and unconcerned about its citizens' character, leaving them alone to decide what constitutes the good life. ${ }^{91}$ Liberal states are not neutral-they seek not only to protect but produce citizens with liberal dispositions, even if the state "as a school of virtue is the last thing a liberal regime conceives itself to be." The Singapore state unabashedly adopts "an ethical, educational, even spiritual role" in nurturing civic virtue and "public spiritedness."

Second, the language of affect and appeal to intangible values is becoming more prominent within a polity where efficiency is prioritized and rationality valorized. Religion may speak in an emotional or affective key, but so does civil religion; cold rationality alone cannot foster solidarity. Government leaders increasingly appreciate the need to engage both the head and heart in describing harmony and the Singapore way as "not just tolerating other groups but opening our hearts to all our fellow citizens." ${ }^{\text {"93 }}$ In a similar vein, PM Lee in 2015 noted the historic "shared moment of sorrow," where the nation as "one Singapore family" mourned the passing of PM Lee Kuan Yew; this crystallized "the Singapore spirit" such that "[n]ow we know that we are Singaporean."

Despite the absence of a constitutional founding moment channeled through a constituent assembly or some analogue, government leaders have lately begun to refer to "our founding fathers" to invoke an air of mythos and moment who enshrined multiracialism into the Constitution and authored the National Pledge under which Singaporeans "pledge ourselves as one united people, regardless of race, language or religion." ${ }^{5}$ A now identifiable "Singapore Story" sets forth a shared vision of "prospering together, progressing together" to make "this little red dot shine bright in the world, as well as in our hearts ..." 96 The national narrative is no longer one of mere struggle, but of attainment. There is now a "way of life" to safeguard, where majority and minority groups interact to "increase common space" and resist the global "tide of populism"97 and ethnic chauvinism.

In 2017, the Law Minister, while affirming the religious freedom of all, urged that as a community "we must covenant to ourselves to never allow xenophobia and majoritarianism" 98 to compromise minority protection. A covenant speaks to enduring partnership; ${ }^{99}$ the enemies of this covenant seek to alienate Singaporeans. He particularly cautioned against Islamophobia in stereotyping Muslims as terrorists, exhorting non-Muslims to "embrace our Muslim brothers and sisters" 100 to prevent them from becoming alienated, imperiling "the harmonious society that we have built." 101 The project of sustaining racial and religious harmony continues, with the government seeking to partner ${ }^{102}$ with civil society and religious leaders to build social trust, as "peace between religions" does not come naturally, but is "a constant work in progress." 103

\footnotetext{
${ }^{91}$ Charlene Tan, Creating “Good Citizens" and Maintaining Religious Harmony in Singapore, 30 BRITISH J. RELIGIOUS ED. 133, 133-42 (2008).

${ }^{92}$ Bellah \& Hammond, supra note 30.

${ }^{93}$ NDR 2009, supra note 65.

${ }^{94}$ National Day Rally Speech, supra note 88.

${ }^{95}$ Prime Minister Lee Hsien Loong, supra note 3.

${ }^{96}$ Prime Minister Lee Hsien Loong, Debate on President's Address in Parliament, May 16, 2018.

${ }^{97}$ Salleh, supra note 6.

${ }^{98}$ Salleh, supra note 6 .

${ }^{99}$ Daniel J. Elazar, Covenant as a Political Concept, Jerusalem Center for Public Affairs, (Sept. 24, 2018) http://www. jcpa.org/dje/books/ct-vol1-ch1.htm.

${ }^{100}$ Danson Cheung, Guard Against Rise of Anti-Muslim Sentiment in Singapore: K. Shanmugam, Straits Times (June 5, 2017), https://www.straitstimes.com/singapore/guard-against-rise-of-anti-muslim-here-says-shanmugam.

${ }^{101}$ Walter Sim, Collective Effort Needed to Safeguard Racial, Religious Harmony in Singapore: Shanmugam, STRAITS TIMES (Jan. 19, 2016), https://www.straitstimes.com/singapore/collective-effort-needed-to-safeguard-racial-religious-harmony-insingapore-shanmugam.

${ }^{102}$ Fostering Close Inter-Religious Ties Has to be an Effort by All: Shanmugam, TODAY (Oct. 13, 2017), https://www. todayonline.com/singapore/fostering-close-inter-religious-ties-has-to-be-an-effort-be-all-shanmugam.

${ }^{103} I d$.
} 


\section{Source and Content of CCR}

\section{Legal Framework}

The Article 15(1) guarantee of religious freedom is qualified by Clause (4), which prohibits acts "contrary to public order, public health or morality." No explicit clauses refer to religious harmony, ${ }^{104}$ which may be seen as a subset of public order. The MRHA thus is a vehicle for giving expression to the particular kind of public order advocated by the executive which dominates and drives the legislative agenda.

The MRHA establishes a fifteen-member Presidential Council for Religious Harmony (PCRH) composing religious representatives and other members who have "distinguished themselves in public service or community relations." 105 Through working together and dialogue, this institution facilitates relationship-building. The PCRH reports and makes recommendations to the Minister on referred matters. The MRHA empowers the government to issue restraining orders against religious group leaders or members on four grounds, such as using religion to promote political causes or subversive activities, or "causing feelings of enmity, hatred, ill-will or hostility between different religious groups." ${ }^{06}$ While no MRHA restraining order has ever been issued, there is public awareness of this Act: A Buddhist group sees the MRHA as a shield "against insensitive proselytizing." 107

Sanctions for disrupting religious harmony are imposed through legislation like the Sedition Act - which defines seditious tendency as including acts involving "feelings of ill-will and hostility between different races or classes of the population of Singapore"108 — and Sections 298 and 298A of the Penal Code relating to wounding religious feelings or acts done to disrupt religious or racial harmony. The Manpower Ministry refuses Miscellaneous Work Passes to foreign religious preachers whose teachings are deemed divisive in advocating "violence or promoted segregationist, intolerant teachings." ${ }^{109}$ Burning the Bible or Quran is not protected speech. Thus, a "tough framework of laws" touching on what "you can or cannot say about race and religion" are set in place. ${ }^{110}$ The underlying principle is: "[D]o not do harm unto others, do not advocate violence, do not put down somebody else's religion. As long as you keep to that, propagate your faith." 111

\section{Source}

Affect and legal sanctions are unhappy bedfellows. While the law can "prevent negative actions" and have an educative effect in "[making] people understand and take care" not to act in an antisocial fashion, law and legal sanction cannot "creative positive feelings" or "a positive community," which needs efforts that "go beyond" the law. ${ }^{112}$ Constructing a CCR must be by way of persuasion, as diktat breeds alienation.

\footnotetext{
${ }^{104}$ Article $51(\mathrm{~A})(\mathrm{e})$ of the Constitution of India declares it a fundamental duty of all citizens "promote harmony and the spirit of common brotherhood amongst all the people of India transcending religious, linguistic and regional or sectional diversities."

${ }^{105}$ MRHA $\$ 3$.

${ }^{106}$ MRHA $\$ 8(1)(a)-(d)$.

${ }^{107}$ Agree to Disagree: Conversations on Conversion 18 (2010) (ebook).

${ }^{108}$ Sedition Act $\$ 3(1)(e)(1948)$.

${ }^{109}$ Kasiviswanathan Shanmugam, Home Affairs Minister, Decision to Refuse Entry to Foreign Religious Preachers, 94 SPR, (Aug. 1, 2018). Two Christian preachers were banned from coming into Singapore. One described Allah as "a false god" and referred to Buddhists by a Hebrew word (Tohuw) which means "lost, lifeless, confused and spiritually barren." The other said Islam was "not a religion of peace" and was interested in "world domination." Both had made "denigrating and inflammatory comments of other religions" in the past which were "unacceptable in multiracial, multi-religious Singapore," according to the Home Affairs Ministry. Elgin Toh, Two Foreign Christian Preachers Denied Entry into Singapore, STRAITS TIMES (Sept. 9, 2017), https://www.straitstimes.com/politics/two-foreign-christian-preachers-denied-entry-into-spore.

${ }^{110}$ Need to Guarantee Position of Minorities, supra note 87.

${ }^{111}$ Shanmugam, supra note 109.

${ }^{112}$ Sim, supra note 101 .
} 
The sources for this CCR religion are found in the extra-documentary constitution, the constitution beyond the court. This views the constitution through a realist lens as a living institution; Karl Llewellyn, in analyzing the US Constitution, described it as being "in essence not a document but a living institution built ... in first instance around a particular Document."113 Rather than words, an institution is "a set of ways of living and doing." Evidence of its existence resides in the fact that people behave "in certain patterns" and "do not behave in other conceivable patterns." 114 A constitution as institution "consists of the ways and attitudes of varied people."115 To apprehend the "complete" constitution, one must appreciate that political and bureaucratic actors, even civil society, also "interpret important constitutional elements through their beliefs, statements and actions." ${ }^{\prime 16}$ The CCR operates within the parameters of the Article 15(1) guarantee of religious freedom, subject to the Clause (4) public order qualification, and speaks to the nature of this public order which goes beyond an absence of law and order, to encompassing a relational dimension that seeks to preserve the longevity of social relationships through shared norms and commitments to solidarity-promoting dispute resolution methods to secure the goal of religious harmony.

A constitution is formally changed through constitutional amendment or judicial interpretation. ${ }^{117}$ The extra-documentary constitution, however, develops differently. In Westminster-based parliamentary systems, unwritten, judicially unenforceable conventions embodying political custom or constitutional morality influence how public power is exercised, evolve out of historical practice. Another important source of the extra-Documentary constitution, particularly within the Singapore context where the parliamentary executive operates within a dominant party state which has not seen political turnover since independence, is soft constitutional law (SCL) norms. Unlike conventions, these are declaratory in nature; these executive-authored SCL norms prescribe standards of behavior articulated in publicly accessible instruments like white papers and declarations. While not legally binding, SCL norms carry persuasive weight, given the political clout of their authors, and play some role in developing the constitution as a living institution in this informal way. A form of quasi-law, SCL norms interpret and may flesh out the content of constitutional provisions, such as what religious harmony as a facet of public order entails. SCL norms generate expectations or express aspirations, which are constitutional interests frequently articulated in constitutional preambles, directive principles and duties. They are hortatory in nature, though they operate within the legal framework with its institutionalized imposition of legal sanctions and rights protection through judicial review. While not permanent, widely known SCL norms ${ }^{118}$ bear some stability and possess predictive value flowing from their social ordering capacity.

For example, a 1999 white paper on Principles Governing National Reserves ${ }^{119}$ recorded "agreed rules of conduct" by which the president and government would operationalize the constitutional regime protecting past financial reserves. The "constitutional practice" embodied in the Principles was open to "future evolution and refinement" and would bind future presidents and

\footnotetext{
${ }^{113}$ Karl Llewellyn, The Constitution as Institution, 34 Colum. L. Rev. 1, 3 (1943).

${ }^{114} I d$. at 17.

${ }^{115} I d$. at 26 .

${ }^{116}$ Matthew Palmer, Using Constitutional Realism to Identify the Complete Constitution: Lessons from an Unwritten Constitution, 54 Am. J. Comp. L. 587, 590 (2006).

${ }^{117}$ The courts have declared implied constitutional principles such as the rule of law, separation of powers, and fundamental rules of natural justice, for example.

${ }^{118}$ White papers are public documents and other instruments like declarations that are available on official government websites.

${ }^{119}$ Principles for Determining and Safeguarding the Accumulated Reserves of the Government and the Fifth Schedule Statutory Board and Government Companies (Paper Cmd. No. 5 of 1999), available at http://www.nas.gov.sg/ archivesonline/government_records/Flipviewer/grid_publish/1/12ec06c2-4a32-11e7-9199-0050568939ad-Cmd.5of1999/ web/html5/index.html?launchlogo=tablet/GovernmentRecords_brandingLogo_.png.
} 
governments unless both parties agreed to amend or abandon the Principles, or one party formally notifies the other it no longer wishes to abide by them. They are thus stable until altered or abandoned, generating expectations of adherence. These SCL norms also inform public rituals, that is, the evolution of a certain protocol for managing or resolving disputes, thus standardizing desired patterns of action, which is explored below.

The corpus of SCL norms relating to a particular subject-matter may be further developed, not only through public ritual but further authoritative statements by government leaders which may be supported by the verbal or physically expressed agreement of other constitutional actors which solidifies constitutional practice. These may be contained in important, authoritative ministerial statements or speeches at special occasions like the Prime Minister's annual National Day Rally speech. This bears affinity to the raw material of civil religion in other jurisdictions, which may include historical documents and speeches at national celebrations or remembrance ceremonies.

\section{Content of Singapore Constitutional Civil Religion and its Relation to Relational Constitutionalism}

Singapore's CCR is modest and non-evangelical; it espouses no divine mission, consistent with the government's predilection for pragmatic realism and results over rhetoric and ideology. While not invoking a deity, it bears no general antipathy to religious faith.

The prime directive of Singapore CCR is maintaining racial and religious harmony. This is either an independent quasi-constitutional value or an expansive reading of public order, a permissible basis for limiting - but not eviscerating - religious liberty under Article 15. This tenet is considered integral to the rule of law. Law Minister Jayakumar noted that while different racial and religious communities have disparate values, all had to respect the rule of law which, in its generality, sets forth "common ground rules of engagement and conflict resolution." Society needs a "large common secular space that belongs to all citizens regardless of race, language or religion." ${ }^{\prime 20}$ This does not connote an assimilationist ethos but recognizes an irreducible plurality and indivisible unity to be safeguarded and nurtured.

The core texts of this CCR creed are found in the government authored 1989 Maintenance of Religious Harmony white paper (MRHWP) and the 2003 Declaration on Religious Harmony $(\mathrm{DRH}),{ }^{121}$ formulated by religious representatives under a junior minister's leadership. It is also one of five shared values ${ }^{122}$ composing a national ideology which "all races and faiths can subscribe to and live by," as no proposal conflicting "with the teachings of Islam, Christianity, Hinduism, Taoism or Buddhism is likely to gain general acceptance." 123

The MRHWP states that religious harmony is "fundamental" to Singapore's "long term stability," that Singaporeans should share a "firm common understanding" of what this required and "abide scrupulously by the ground rules of prudence and good conduct." 124 It identifies threats to religious harmony and guidelines on how to avoid this. The $\mathrm{DRH}$ is framed as a code or citizen's pledge to "strengthen religious harmony through mutual tolerance, confidence, respect and understanding," to guide religious communities in the enjoyment and pursuit of their religious beliefs and practices. It articulates five commitments to:

\footnotetext{
${ }^{120}$ Deputy Prime Minister Shunmugam Jayakumar, The Meaning and Importance of the Rule of Law, IBA Rule of Law Symposium (Oct. 19, 2007), at 17-19.

${ }^{121} \mathrm{Li}$-ann Thio, Constitutional 'Soft' Law and the Management of Religious Liberty and Order: The 2003 Declaration on Religious Harmony, SING. L.J. STUD. 414 (2004).

${ }^{122}$ Shared Values White Paper, (Paper Cmd. No. 1 of 1991), available at http://eresources.nlb.gov.sg/printheritage/detail/ 016ff3de-843f-4e35-8410-7d6dd3fbb66b.aspx.

${ }^{123} I d$. at para. 18. Minority religions — such as the Jehovah's Witnesses-experience less protection of their religious freedoms as their pacifist beliefs clash with compulsory military service.

${ }^{124}$ MRHWP, supra note 79 , at para. 46.
} 
Recognize the secular nature of our State,

Promote cohesion within our society,

Respect each other's freedom of religion,

Grow our common space while respecting our diversity, [and]

Foster inter-religious communications.

While public order relates to the absence of disorder or disturbed public tranquility, religious harmony is a qualitatively different concept, implicating the quality of relationships. This dovetails with the objectives of relational constitutionalism to secure "the relational well-being of individuals and groups and to preserve sustainable relationships," allowing citizens to "maintain their distinct identities, while being unified by a national identity and a shared commitment to the common good." 125

Religious harmony as a constitutional value is not necessarily a restrictive public order norm oppositional to religious liberty; it can be viewed as integral to religious freedom by securing the rights of others and those conditions necessary for community maintenance. It may be conceptualized as an expansive conception of public order, shaped by substantive commitments to deliberative democratic processes and peaceful coexistence. Harmony is not a synonym for conformity or uniformity, nor does it require silence where human rights are violated; if harmony relates to common welfare, this fuels the importance of speaking out against injustice. Harmony as a way of optimizing liberty, solidarity, and order may be a way to realize rights without rightism, connoting a commitment to a shared life, an ethos of tolerance, moderation, and handling disharmony through civil dialogue and reconciliation. ${ }^{126}$

The MRHWP considers that if Singaporeans "show respect and tolerance for other faiths, harmony should prevail." 127 Four major threats to religious harmony may be identified-two of which are articulated in the MRHWP_relating to impaired inter-religious group harmony.

\subsection{Aggressive Proselytization}

First, one major threat is aggressive and insensitive proselytization. The government urges that the constitutional right to propagate faith ${ }^{128}$ be "exercised very sensitively," ${ }^{29}$ without "denigrating other faiths" or insensitively attempting "to convert those belonging to other religions," as this could spawn offense. This is an executive interpretation of the scope of a constitutional liberty. Since independence, the government policy is to discourage the evangelization of the MalayMuslim community.

The government apprehends that "when religious sensitivities are offended emotions are quickly aroused." As religion is a "deeply felt matter", only a few incidents could "inflame passions, kindle violence" and destroy "the good record of religious harmony ...." 130 Even without direct proselytization, religious instruction could cause harm. Though it was legitimate to point out divergences with other belief systems in the course of religious instruction, unrestrained preachers denouncing non-believers as "misguided infidels and lost souls" could "cause great umbrage to entire communities." Trust would be undone if virulent retaliation ensued; attacking persons and places of worship belonging to other faiths ${ }^{131}$ would generate ill-will and conflict. Religious groups should be cognizant of "the sensitivities" of other religious groups, respect

\footnotetext{
${ }^{125}$ Thio Li-ann, Relational Constitutionalism and the Management of Religious Disputes: The Singapore 'Secularism with a Soul' Model, 1 Oxford J.L \& Religion 446 (2012).

${ }^{126}$ Stephen C. Angle, Human Rights and Harmony, 30 Hum. RTS. Q. 76 (2008).

${ }^{127}$ MRHWP, supra note 79, at para. 13.

${ }^{128}$ MRHWP, supra note 79 , at para. 15.

${ }^{129}$ MRHWP, supra note 79 , at para. 15.

${ }^{130}$ MRHWP, supra note 79 , at para. 11 .

${ }^{131}$ MRHWP, supra note 79, at para. 16. The government seeks to preempt this conflict by denying work passes to foreign preachers with a track record of "radical preaching and teaching" which is intolerant and segregationist, so as not to give them
} 
individual freedom of conscience, and disallow their members from "acting disrespectfully" or inciting violence or hostility against other groups. ${ }^{132}$ These rules of prudence cater to the Emotional Man rather than the Rational Man able to tolerate offensive speech in the interests of free speech and the pursuit of truth. The CCR tenet of religious harmony operates in this instance to balance religious freedoms against religious sensitivities as a facet of public order and relational solidarity; it does not impose a blanket ban on religious propagation but seeks to regulate the style of its exercise.

\subsection{Mixing Religion and Politics}

The second threat occurs when religion and politics are mixed, specifically when religious groups pursue secular political objectives by using religious authority for political mobilization. If one does this, others will follow and politicians may then try to curry favor with religious groups.

The soft norms in the MRHWP do not preclude citizens with religious convictions from participating in democratic processes, as it is "neither possible nor desirable to compartmentalize completely the mind of voters into secular and religious halves." ${ }^{33}$ Religious leaders are urged not to incite their fellow religionists "to defy, challenge or actively oppose secular Government policies" or to perform subversive activities. ${ }^{134}$ Religious leaders should express their political views circumspectly. So although the fatwa committee considered that Islam prohibited abortion-which Singapore law permits - the Muslim leadership adopted the track of educating the faithful rather than mounting a public campaign against government policy, which could precipitate "disharmony and unhappiness." 135 To preserve religious harmony, religious groups should mutually abstain from seeking "competitive political influence". ${ }^{136}$ Social tensions would be heightened if religious groups - and presumably irreligious groups-were to become active political forces seeking to advance their agenda.

The MRHWP does not advocate for a complete separation of religion and politics, which is well-nigh impossible given the absence of objective criteria or a neutral arbiter to delineate these spheres. Religious faiths have informed the social conscience in speaking out against injustice, though there will be clashes in plural societies given disparate views on controversial matters like abortion. Legislatively mandated military service trumps the conscientious objections of Jehovah's Witnesses, for example. ${ }^{137}$ Religion and politics are not hermetically sealed compartments; the MRHWP appreciates that not all faiths accept a division between religion and politics; it notes the danger of religious groups seeking to fully implement "their respective visions of an ideal society." 138 Short of divine intervention, such totalizing or comprehensive utopian or messianic visions must be held in abeyance within plural societies to preserve a secular democracy where religious freedom is protected and civil peace maintained. Singaporeans should appreciate that the practice of their faith must take place within the context of a multi-religious society.

To this end, the MUIS produced a "Risalah For Building a Singapore Muslim Community of Excellence" 139 with ten Desirable Attributes to help the community be "religiously profound and socially progressive," adapting religious teachings to modern exigencies and charting "our own

a direct physical platform to spread their teachings in Singapore, even if these are available online. Shanmugam, supra note 109.

${ }^{132}$ MRHWP, supra note 79 , at para. 18.

${ }^{133}$ MRHWP, supra note 79 , at para. 24.

${ }^{134}$ MRHWP, supra note 79, at para. 20.

${ }^{135}$ Zalman Putra Ahmad Ali \& Zainul Abidin Ibrahim, Spirit of Blessings to All: MUIS' Contribution to Social Cohesion, in Fulfilling The Trust: 50 Years Of Shaping Muslim Religious Life In Singapore 255, 261 (Norshahril Saat ed., 2018) [hereinafter 50 YEARS].

${ }^{136}$ MRHWP, supra note 79, at para. 28.

${ }^{137}$ MRHWP, supra note 79 , at para. 26.

${ }^{138}$ MRHWP, supra note 79 , at para. 25.

${ }^{139}$ Majlis Ugama Islam Sinagpura, Riselah for Building a Singapore Muslim Community of Excellence (2nd ed. 2006), https:// www.muis.gov.sg/-/media/Files/OOM/Resources/Risalah-eng-lr.pdf [hereinafter Riselah]. 
path in living Islam today" as loyal, contributing citizens who uphold the CCR tenet of religious harmony. Credible Islamic scholarship supports the view that Muslims can coexist with other communities in diverse societies, while provocative doctrines like ISIS's view on hijrah (migration to Islamic lands) — which holds that Muslims cannot live under non-Muslim rule-is rejected. ${ }^{140}$ An organization of Islamic teachers took the position at a 2003 conference that, because the possibility of implementing comprehensive Islam was remote, they could "accept Singapore being a secular state," provided the government continued to be religiously non-partisan and ensured religious harmony and the reasonable enjoyment of religious freedom. ${ }^{141}$

\subsection{Extremist Religious Teachings Advocating Violence}

A third threat to religious harmony is extremist religious ideology advocating terrorism. After 9/11, the government is ever wary of radicalized Islam, where groups such as the Jemaah Islamiyah (JI) which had Al Qaeda links — seek to establish a sultanate in Southeast Asia. This threat came to the fore after a failed JI plot to bomb the US embassy and MRT stations in Singapore in 2001-2002. ${ }^{142}$ The conspirators were preventively detained under the Internal Security Act (ISA) and a white paper on the Jemaah Islamiyah Arrests and the Threat of Terrorism was issued in 2003 containing evidence of the conspiracy. The government adopted a relational approach in seeking to assuage the fears of a beleaguered Muslim community by convening public meetings and closed-door consultations with religious and community leaders. The conspirators' families were assured that their relatives were being treated well. Damage control extended to conducting school briefings to calm the situation. The JI white paper referenced the Maintenance of Religious Harmony white paper (MRHWP) principles of religious toleration and moderation, as well as keeping religion and politics separate. ${ }^{143}$

As terrorism conducted in a religion's name can fundamentally impair inter-religious ties and deplete the national store of "psychological strength,"144 the white paper sought to characterize the terrorists as a "small and isolated group of misguided Muslims with no support from the community," 145 manipulated by radical foreign teachers who exploited "the deeply-felt sense of Islamic brotherhood" and traditional respect accorded to religious teachers. These were contrasted against the vast majority of "moderate, tolerant and law-abiding"146 Singapore Muslims. The government also worked hard to ensure that Muslims "understood that the JI arrests were about terrorism and not about anti-Islam."147

Articulating a dichotomy between both the militant and the moderate, and the local and the foreign, was an attempt to provide a framework for the public to approach the issue of religious extremism and to preserve trust with the moderate and local. Indeed-cognizant of sensitivitiesgovernment leaders urge the disassociation of terrorism from any one religion. ${ }^{148}$ The government was careful to note "it must not disrupt the legitimate practices and peaceful activities of the local Muslim community"149 in seeking to identify radical teachers and neutralize foreign terrorist

\footnotetext{
${ }^{140}$ MUIS Statement on Mufti Friday Sermon, Media Statement (Sept. 29, 2017), at para. 6.

${ }^{141}$ Persatuan Ulama dan Guru-Guru Agama Islam Singapura, Moderation in Islam in the Context of the Muslim Community in Singapore 111-12 (PERGAS Ulama Convention, 2003).

${ }^{142}$ The Jemaah Islamiyah Arrests and the Threat of Terrorism White Paper, (Paper Cmd. No. 2 of 2003), available at http:// eresources.nlb.gov.sg/printheritage/detail/2125a7b0-9a25-47ca-bf7f-a74a41a4261b.aspx [hereinafter JI White Paper].

${ }^{143} I d$. at 24 .

${ }^{144} I d$.

${ }^{145} \mathrm{Id}$. at 23

${ }^{146} I d$.

${ }^{147}$ Zainul Abidin Rasheed, Minister of State, Resolving Ethno-Religious Conflicts: The Singapore Experience, 12th Conference of the East and Southeast Asia Network for Better Local Governments (Dec. 2, 2004).

${ }^{148}$ Deputy Prime Minister Teo Chee Hean urged that, in the interests of preserving religious harmony, efforts should be directed to "counter extremism and violence in all forms." Teo Chee Hean, Deputy Prime Minister, Speech, Opening Ceremony of the 17th General Assembly of the Regional Islamic Da'wah Council of Southeast Asia and The Pacific (Oct. 3, 2017).

${ }^{149}$ JI White Paper, supra note 142, at 22.
} 
operatives. The government urged the Muslim community to develop a self-regulatory mechanism to monitor religious education. The relational route of building a cooperative relationship with the Muslim community was taken - to promote their sense of belonging and stakeholding in Singapore-urging the community to be an exemplary role model. ${ }^{150}$ There is some state regulation of religious doctrine, cast as localizing religious teachings to adhere to the CCR tenet of racial and religious harmony: Under Section 87 of AMLA, all Islamic teachers must be registered with MUIS. Religious teachers need a basic competence based certificate and must comply with the Asatizah Recognition Scheme (ARS) Code of Ethics, which requires asatizahs to recognize the plurality of opinions within Islamic teachings and to teach in a manner consistent with maintaining "the well-being and harmony of the society." This requirement involves not denigrating anyone or advocating extremist ideas, ${ }^{151}$ with the goal of guiding Muslims "to live in harmony with other Singaporeans of all races and religions." 152 Like all citizens, religious minorities owe a duty to uphold social order; guidelines in this regard are easier to swallow than binding regulations that augment state power.

The JI white paper also provides soft norms urging Singaporeans to see religious terrorism as a national-rather than Muslim-problem. ${ }^{153}$ This view was later repeated after two auxiliary Malay policemen were detained for terrorism-related offences under the ISA. The government stressed the need for "parents, religious teachers and the community at large" to look out for each other and "report any signs of radicalization" to the Islamic authorities or police, while the Muslim Affairs minister denounced those who abused Islam by espousing extremist ideology to justify terror. ${ }^{154}$ The Prime Minister warned against anti-Muslim sentiment taking root, equating Islamophobia with radical terrorism; ${ }^{155}$ to manage the fallout, the Prime Minister met with Muslim and non-Muslim community leaders to hear their concerns, underscoring that "we are all in this together." 156

\subsection{Islamophobia, Isolationism, and Interfaith Interaction}

The historical record reveals that the terrorist threat and continuing problem of self-radicalization has been associated with groups or individuals who identify as Islamic, the faith of the vast majority of Malays. The perennial fear is that if negatively stereotyped, Malay-Muslims will become isolationist. This effect could cause a backlash when non-Muslims view Muslims "in a negative light," precipitating Islamophobia. ${ }^{157}$ The government has long implemented policies promoting inter-racial integration, such as through schemes requiring that each racial group may take up a certain proportion of flats in a HDB block and precinct to prevent race-based ghettoes.

Ministers have given public speeches about combatting terrorism while guarding against Islamophobia. ${ }^{158}$ For example, a madrasah student recounted at a dialogue session how a joke about Muslims being terrorists had hurt her feelings, whereupon Home Affairs Minister

\footnotetext{
${ }^{150}$ Singapore's Malay Muslims Can Be Modern Vibrant Community That the World Looks Up To: Shanmugam, CHANnEL NewsAsia, Apr. 1, 2017; Nur Asyiqin Mohamad Salleh, Fatwa Committee Has Helped in Building Harmonious, Multicultural Society: Tharman, STRAITS Times, Feb. 11, 2017.

${ }^{151}$ Annex B: Presentation of Certification of Recognition for Muslim Religious Schools, in MUIS FACTSHEET, ASATIZAH ReCognition Scheme Code of Ethics (Oct. 27, 2017).

${ }^{152}$ Prime Minister Lee Hsien Loong, National Day Rally Speech (Aug. 21, 2016) [hereinafter NDR16].

153“All Singaporeans, and not just Muslims, must exercise vigilance against extremist religious teachings and suspicious or clandestine activities." JI White Paper, supra note 142, at 22.

${ }^{154}$ Toh Yong Chuan, Two Auxiliary Police Officers Arrested for Terrorism-Related Offences, STRAITS TIMES, June 20, 2017.

${ }^{155}$ Islamophobia as Unacceptable as Radical Terrorism, Says Prime Minister Lee Hsien Loong, STRAITs Times, June $20,2017$. Prime Minister Lee described the incident of a white man driving a van into a crowd of Muslim worshippers leaving a mosque in London's Finsbury Park as an act of Islamophobia.

${ }^{156}$ Prime Minister Lee Hsien Loong, Opening Remarks, A Dialogue with Community and Religious Leaders (July 24, 2017).

${ }^{157} I d$.

${ }^{158}$ Danson Cheong, Guard Against Rise of Anti-Muslim Sentiment in Singapore: K. Shanmugam, STRAITs Times, June 5, 2017 [hereinafter Guard].
} 
Shanmugam declared that the $85 \%$ of Singaporeans who were non-Muslims "have an obligation to reach out to the Muslim community and make sure the bonds are strong."159

Government ministers have articulated the specific responsibilities expected of different actors. For example, the government would act strongly against acts flowing from anti-Muslim sentiment. Muslim communities had to rebut the association of Islam with extremism to advance "the right approach and the right interpretation" to assure themselves and other non-Muslim communities. Non-Muslims bore the "absolute duty to stamp out xenophobia, stamp out Islamophobia and reach out across to our Muslim brothers and sisters." 160 Everyone should unequivocally condemn terrorist acts to facilitate the on-going project of working for "a united tolerant multi-racial multi-religious society." 161

Optics are important to promote CCR tenets and signal best practices, such as a photo on the Prime Minister's Facebook page showing the Rabbi and Mufti together with a Sikh Leader, not letting their different dietary rules stop them from "having a meal together and being friends together ... Only in Singapore!"162

Religious leaders are now expected to actively champion interaction, integration, and religious harmony for the common good ${ }^{163}$ to ensure their flock was tolerant, "that we greet each other, that we celebrate each other's festivals." 164 This goes beyond prohibitive rules to positive duties.

The Inter-Religious Organization (IRO) plays a leading role in this regard. Formed in 1949 to promote peace and religious harmony, its members represent ten major religions. Thus, when the Jewish community publicly celebrated Hannukah, the IRO Chair was invited to light the Menorah, ${ }^{165}$ an example of how religious leaders "give blessings on one another's milestone celebrations." 166 This promotion goes beyond tolerance to actively sharing religious life. While Indonesian Islamic authorities ${ }^{167}$ issue fatwas against inter-faith prayers, the IRO often prays together publicly for safety before F1 races or at the opening of MRT stations, dressed in their religious accoutrements, a symbolic rejection of exclusivism. ${ }^{168}$ Foreign preachers with divisive messages - such as Ismail Menk's view that it is "the biggest sin and crime" for a Muslim to wish a non-Muslim "Merry Christmas" or "Happy Deepavali"—were denied work passes. MUIS was consulted and did not support these applications to preach as the applicants' teachings "run counter to the values Singaporean Muslims uphold dearly that can contribute to a progressive and thriving religious life in Singapore." 169 In 2018, the Mufti publicly and proactively sent Chinese New Year (CNY) greetings ${ }^{170}$ to the Chinese community, which

\footnotetext{
${ }^{159}$ Chong Zi Liang, Stop Anti-Muslim Views From Taking Root: Shanmugam, STRAITs Times, Mar. 31, 2016.

${ }^{160}$ Kasiviswanathan Shanmugam, Fostering Close Inter-Religious Ties Has to Be an Effort By All: Shanmugam, ToDAY, Oct. 13, 2017 [hereinafter Fostering].

${ }^{161}$ Guard, supra note 158.

${ }^{162}$ Prime Minister Lee Hsien Loong, National Day Rally Speech (Aug. 23, 2015). So, too, Prime Minister Lee stated after the swearing-in of President Halimah Yacob, he "posted a picture on Instagram of myself, President Halimah and Chief Justice Sundaresh Menon. A Chinese, a Malay and an Indian - only in Singapore.” Race, supra note 3.

${ }^{163}$ Nur Asyiqin Mohamad Salleh, Singapore Must Safeguard Position of Minorities Amid Growing Polarisation Abroad: Shanmugam, Straits Times, Feb. 1, 2017.

${ }^{164}$ Shanmugam, Fostering, supra note 160.

${ }^{165}$ IRO President Warmly Invited to Light the Candle at Chanukah Festival 2017, InTER-Religious OrganiZATION, http:// iro.sg/gallery/chanukah-celebration-2017-jewish-festival-of-light/. Rabbi Abergel testified to the "amazing spirit of harmony in Singapore, that we can celebrate a holiday that means so much to use with such pride, peace and safety." Public Lighting of a Giant Menorah in Orchard Road, Straight Times, Dec. 22, 2011, at 2.

${ }^{166}$ Prime Minister Lee Hsien Loong, supra note 3.

${ }^{167}$ The Impact of MUI Fatwas on Freedom of Religion in Indonesia, JAKARTA POST, Aug. 6, 2005.

${ }^{168}$ Singapore Track Blessed Ahead of Annual F1 Night Race, TODAY, Sept. 12, 2013; Religious Leaders Visit Downtown Line 3 Ahead of Launch on Oct 21, ChannelNews Asia, Sept. 25, 2017.

${ }^{169}$ Tham Yuen-C, 2 Foreign Islamic Preachers Barred From Entering Singapore for Religious Cruise, STRAITs TIMES, Oct. 30, 2017.

${ }^{170}$ Cynthia Choo, 'Happy Chinese New Year,'Says S’pore's Top Muslim Leader in Inaugural Greetings, TodAY, Feb. $14,2018$.
} 
demonstrated that Malay-Muslim leaders were contributing towards nurturing and enhancing "the harmonious social environment that we all enjoy today;" as "part of the larger Singapore family," he declared the Muslim community stood united with other communities to continue "to build a cohesive and thriving Singapore for future generations." ${ }^{171}$ This builds on the interfaith initiatives, such as that of Ba'alwie Mosque, which hosts community groups to share about Islam and build friendships.

To promote goodwill, various mosques distributed oranges and greeting cards to Chinese residents in their vicinity. One also delivered rice and groceries to sixty elderly and less privileged households. ${ }^{172}$ The Masjid Yusof Ishyak organized a CNY celebration on its mosque premises where one hundred elderly nursing home patients enjoyed lunch, a song and dance, and gifts of oranges and hongbaos. Education Minister Ong Ye Kung attended and praised this event as exemplifying living together "in harmony as a nation." The mosque staff also attended a Chinese monastery's CNY celebrations, which was praised as promoting inter-religious and cultural understanding. ${ }^{173}$

The government exhorts religious leaders to pursue inter-faith interactions as a curative to segregationist tendencies; to promote mutual understanding and respect, "we cannot treat other groups as infidels." 174 Practicing faith in a multi-religious context requires nurturing relations which are "tolerant, give-and-take, respectful, [and] warm." 175 The CCR tenet of racial and religious harmony promotes the pursuit of friendly relations and goodwill between religious and racial groups. This tenet stands in contrast with the agonistic relations associated with polemical political contestation, identity politics, and the cultural Marxist tactics used in the culture wars to demonize and intimidate political opponents.

The government conceives of the relationships between ethnic and religious communities as one "essentially about emotions," whether people from different races and religions trust each other, feel comfortable living in proximity, and interacting. Law and policy alone in the endeavor of maintaining racial and religious harmony is insufficient, as what is required is "winning hearts and minds" and "influencing the people's emotions." 176 Important work has to be done at the grassroots level where citizens interact with the government and each other. Like any religion, CCR must be nurtured in community life - which we now examine - as the security for harmony lies in sustained efforts "to strengthen the friendships and develop trust among Singaporeans from different cultures and religions." 177

\section{Institutions and Networks}

Singapore CCR has its equivalent of a sacred text which records the mantra of racial and religious harmony, and its adversary, which threatens disharmony. It has its priests, such as the Islamic religious teachers whose ethics code requires that religious teachings do not impair social harmony. Asatizahs also seek to guide youths through their social media presence, which reassures non-Muslims that the Muslim community is taking "firm steps"178 to combat the common enemy

\footnotetext{
${ }^{171}$ Dr. Mohamed Fatris Bakaram, Mufti of Singapore, Lunar New Year Greetings, TodAY (Feb. 14, 2018), http://interactive. todayonline.com/gallery/uploads/1518606517_690267_muftislu_n.jpg.

${ }^{172}$ Mosques Join Spreading CNY Cheer, STRAITs Times, Feb. 15, 2018.

${ }^{173}$ Jewel Stolarchuk, Mosque Draws Flak From Netizens for Organizing CNY Celebration in its Premises, INDEPENDENT SG, Feb. 27, 2018. Some netizens criticized having a song and dance in a sacred space like a mosque.

${ }^{174}$ NDR16, supra note 152.

${ }^{175}$ NDR16, supra note 152 .

${ }^{176}$ Rasheed, supra note 147.

${ }^{177}$ Deputy Prime Minister Teo Chee Hean, Strengthening Multi-Religious Relations for a Harmonious, Secure, and Caring Society, 85th Anniversary Gala Dinner of Jamiyah Singapore (Oct. 14, 2017).

${ }^{178}$ Deputy Prime Minister Teo Chee Hean, supra note 148.
} 
of violent extremism. The new blasphemy is to denigrate others' faiths or to stir ill-will against a religious group as a form of sacraphobia.

The CCR is sustained by a community of adherents crossing racial and religious lines. After the Jemaah Islamiyah conspiracy was unearthed in 2001, PM Goh Chok Tong stated his confidence that, at the leadership level, "good sense will prevail" in addressing racial and religious incidents and that reactions would be "calm, considered and based on facts." He voiced concern that the ordinary citizen would "react emotionally based on rumors, hearsay and prejudices" and that irrational conduct could lead to a "major confrontation" between races and religions. ${ }^{179} \mathrm{He}$ proposed a code to "crystallize the consensus" on the conduct of religious life in Singapore. He instructed the People's Association in 2002 to set up Inter-Racial Confidence Circles (IRCC) -renamed the Inter Racial and Religious Confidence Circles in 2007-at the community level as platforms to promote confidence-building between the different communities and to promote "deeper friendships and trust." 180 The IRCCs ${ }^{181}$ also train to be rapid responders in the event of racial and religious tension and to project solidarity during crises.

During the drafting of the Declaration on Religious Harmony (DRH) — which was presented as "a product of a bottom-up consultation process involving all major stakeholders," 182 and the People's Document ${ }^{183}$ — the religious representatives involved in this enterprise, steered by a junior minister, were not only sensitized to each other's concerns, but they also developed relational networks and were later appointed to a shepherding body to promote the DRH to the community at large. In promoting desirable behavior, the DRH is preventative in nature; whether it is observed depends on good-will and self-regulation.

Just as all religions have sacred or memorial days, the DRH was first recited by grassroots bodies, students, and religious groups during the Racial Harmony Day Celebrations in 2003. ${ }^{184}$ The CCR has pastoral ministers, in the form of the Religious Rehabilitation Group (RRG), composed of Islamic teachers who counsel and rehabilitate radicalized individuals, such as those detained in the Jemaah Islamiyah conspiracy. This rehabilitation has expanded to include public education initiatives to counter misinterpretations of Islamic concepts and prevent extremist narratives "from dominating the community's religious discourse." 185 The RRG plays a peacebuilding role in promoting an appreciation of Islam and inter-faith understanding. ${ }^{186}$

The shrines where the CCR is celebrated include the Harmony Centre ${ }^{187}$ established in 2006 as MUIS' inter-faith arm; its location in An-Nahdhah Mosque is groundbreaking. The Centre has Islamic exhibits and also provides information on other religions such as Hinduism, Taoism, and Buddhism, stressing the importance Islam places on pluralism ${ }^{188}$ and showcasing "Singapore's model of religious harmony." 189 To foster inter-religious dialogue, it runs a "Building Bridges" program, collaborating with the National Council of Churches of Singapore in 2011 and the Buddhist community in $2014 .{ }^{190}$ It sponsors a flagship lecture series where apex religious leaders address a wider interfaith audience. The Harmony Centre also sends gifts to Buddhist and Taoist

\footnotetext{
${ }^{179}$ JI White Paper, supra note 142 , at 23.

${ }^{180}$ JI White Paper, supra note 142 , at 23.

${ }^{181}$ There are eighty-nine IRCCs, one for each constituency. INTER-RACIAL AND RELIGIOUs ConfidenCE CIRCLE, https:// www.ircc.sg/ (last visited Aug. 4, 2019).

${ }^{182}$ Press Statement, Declaration of Religious Harmony, para. 6 (June 9, 2003) [hereinafter Declaration of Religious Harmony]; Speech by Mr. Chan Soo Sen, Minister of State for Community Development and Sports and Educuation, Feb. 28, 2004, available at http://www.nas.gov.sg/archivesonline/speeches/view-html?filename=2004022898.htm.

${ }^{183}$ The Declaration opens with the phrase, "We the people in Singapore." Id.

${ }^{184}$ A Religious Harmony Pledge for Everyone, STRAITs TimES, July 19, 2003, at 15.

${ }^{185}$ Ali \& Ibrahim, 50 Years, supra note 135, at 263.

${ }^{186}$ Deputy Prime Minister Teo Chee Hean, 13th Religious Rehabilitation Group Retreat, Mar. 14, 2017.

${ }^{187}$ Nur Asyiqin Mohamad Salleh, Muis' Harmony Centre Drawing Interest From Abroad, Straits Times, Jan. $2,2014$.

${ }^{188}$ Natasha Lakhpathy, The Harmony Centre, An-Nahdhah Mosque, The IsMaILI, Nov. 13, 2007.

${ }^{189}$ Ali \& Ibrahim, 50 Years, supra note 135, at 267.

${ }^{190}$ Ali \& Ibrahim, 50 Years, supra note 135 , at 268.
} 
leaders to celebrate the Chinese New Year. ${ }^{191}$ The Home Affairs Ministry developed a "Harmony in Diversity" gallery designed to enrich understandings of Singapore's rich religious diversity and to appreciate that religious harmony is a constant work in progress. ${ }^{192}$ Consonant with CCR tenets, exhibits and displays seek to emphasize the importance of seeking common ground, expanding common spaces, and encouraging personal reflection on how individuals can help sustain a harmonious Singapore.

The government runs a harmony fund-the CCR's evangelical arm-to support projects promoting religious harmony with grants up to $\$ 100,000$. The fund awarded a grant to the youth group "Roses for Harmony," which acts as CCR ambassadors for inter-faith harmony, and whose patron since 2012 is the President. It seeks to build an inter-faith network of youths and train them to become "peace ambassadors, interfaith leaders and lifelong catalysts of inter-religious cooperation." 193 MUIS intends to develop a broader alliance among such interfaith groups in order to build a "stronger voice of reason, moderation and toleration" to serve religious harmony. ${ }^{194}$ The government encourages such grassroots initiatives, as the religious harmony project requires civil society and religious leaders to work "in partnership" 195 with the government as adherents to a common creed.

\section{Dispute Resolution: Disharmony Disputes, Public Ritual, and Relational Constitutionalism}

The court-centric theory that rules decide cases creates - in the aftermath of adjudication - both a winner and a loser. This result breeds alienation and separation, rather than reconciliation and solidarity, the object of relational constitutionalism. Officialdom also fears that judicial proceedings over religious disharmony disputes may be a venue for stoking public passions.

To preserve the relationship of parties to a disharmony dispute, nonjudicial dispute resolution has to be oriented towards a settlement which allows for a continuing relationship and community rapprochement; any disciplining response cannot be disproportionate, humiliating, vengeful, or animus-sustaining. This notion requires goodwill on the part of those involved and a commitment to heal the relational breakdown and seek reconciliation. A rights-based approach to ordering social relations cannot accomplish this.

Typically, a disharmony incident involves religious group A doing something which offends the sensitivities of religious group(s) B. A complaint is made to the authorities, either by the offended religious party or by militant secularists who-as conflict entrepreneurs-seek to stir inter-religious tensions to serve some ulterior purpose guised under the umbrella of preserving religious harmony. The authorities may take legal action or issue a warning to the offending party.

From a study of various disharmony incidents, such incidents are framed as breaching the CCR tenet of religious harmony through antisocial behavior, eliciting collective disapproval and the prospect of legal sanction. A protocol or conciliation oriented, solidarity projecting public ritual has emerged over time with respect to the desired conduct expected of various parties to a disharmony crisis, which may be described as CCR in action. This has precedential value, where actions comply with expectations and CCR norms as part of the Constitution as a living institution provide the shared basis from which the dispute is managed. The offending and offended religious parties take center stage, while the legal framework and watchful government recede to the background and reemerge only after the reconciliatory public ritual is successfully executed to ratify the settlement. This process usually involves an express acceptance that SCL norms in MRHWP provide the appropriate framework for managing the issue, which reaffirms the authoritativeness of CCR norms for addressing disharmony problems. This affirmation sustains the perception that

\footnotetext{
${ }^{191}$ Mosques, supra note 172.

${ }^{192}$ Harmony in Diversity Gallery, https://www.harmonyindiversitygallery.sg/ (last visited Aug. 6, 2019).

${ }^{193}$ Theresa Tan, Roses to Spread Peace, Sunday Times, Feb. 4, 2018, at B7.

${ }^{194}$ Ali \& Ibrahim, 50 Years, supra note 135, at 271.

${ }^{195}$ Shanmugam, Fostering, supra note 160.
} 
the government is not acting in a heavy-handed interventionist manner, which can alienate faith communities, contrary to the goals of CCR. How the government responds to third party conflict entrepreneurs seeking punitive action to fuel tensions or weaponize the situation for political gain will impact the sustainability of the settlement between the religious parties. What follows is an analysis of three case studies with a view to illustrating an alternative dispute resolution method which applies and develops the CCR in its goal of sustaining solidarity and repairing the relational breach to restore the status quo ante of religious harmony.

\section{Lighthouse Evangelism Disharmony Incident ${ }^{196}$}

Complaints were made against videos made by Pastor Rony Tan on the Lighthouse Evangelism church website, which some Buddhists and Taoists found offensive for mocking their beliefs. After receiving a public warning from the Internal Security Department, the videos were removed, but by then had been reposted on platforms like Facebook and YouTube. The internet was abuzz with harsh criticism of the pastor who appealed for the removal of these reposted clips and who also reviewed the church inventory of uploaded videos for offensiveness.

Pastor Tan personally visited representatives of the Buddhist and Taoist Federation to apologize, which was graciously received. The media printed reconciliatory photos of them hugging, which decelerated tensions. Only then did Home Affairs Minister Wong Kan Seng signal that he was "heartened" by the accepted public apology, commending the measured response of Buddhist and Taoists leaders in urging restraint among their religious communities. Minister Wong affirmed that religious propagation was a constitutional liberty but referenced various SCL norms to underscore that it should not be exercised "by way of insulting or denigrating the religious beliefs of others." ${ }^{197}$ The Buddhist and Taoist leaders stated they intended to stay in touch with Pastor Tan and cooperate to promote mutual understanding between their respective religious groups. ${ }^{198}$ This was not satisfactory to certain netizens who-as self-anointed champions of religious harmony-continued to vilify or demonize the pastor online and to insult Christianity in general. Some netizens started a Facebook campaign calling for the Pastor's arrest in the name of "embracing religious harmony," which the government ignored. ${ }^{199}$

\section{Imam Nalla Mohammad}

A video shot and uploaded to Facebook on February 24, 2017 by Nunis—a Muslim Singaporean —of Iman Nalla Mohammad went viral; in it, the Imam who worked at Jamae Mosque since 2010 uttered an Arabic prayer, "God help us against Jews and Christians," which was deemed offensive to Christians and Jews. A Muslim academic, Aljunied, made comments on Facebook which could be construed as supporting the Imam's remarks.

Nalla was convicted under Section 298 A(b) of the Penal Code (Cap 224) for committing an act he knew was "prejudicial to the maintenance of harmony between different religious or racial groups and which disturbs or is likely to disturb the public tranquility." Nunis and Aljunied received stern warnings, Nunis for posting the video online rather than reporting it to the police. Both men expressed regret and issued public apologies. ${ }^{200}$

\footnotetext{
${ }^{196}$ Li-ann Thio, Contentious Liberty: Regulating Religious Propagation in a Multi-Religious Secular Democracy, SING L.J. STUD. 484 (2010).

${ }^{197}$ MHA Statement in Response to Media Queries on the Lighthouse Evangelism Videos and Comments Made By Pastor Rony Tan of Lighthouse Evangelism, Ministry of Home Affairs, available at https://www.asiaone.com/News/AsiaOne\% 2BNews/Singapore/Story/A1Story20100209-197643.html (Feb. 8, 2010).

${ }^{198}$ We Hope He Has Learnt a Lesson, Straits Times, Feb. 10, 2010, at 1.

${ }^{199}$ For example, two Facebook groups_ “Arrest Pastor Rony Tan” and "Embrace Religious Harmony! Disgrace to Zealots like Rony Tan" - called for arrest, and one made the illiberal suggestion of banning proselytization. Concerned Netizens Hurt By Christians, Christian Post, Feb. 12, 2010 (on file with author).

${ }^{200}$ Toh Yong Chuan, Duo Warned for Uploading, Supporting Video, STRAITs Times, Apr. 4, 2017.
} 
Imam Nalla was fined $\$ 4,000$ and deported. Notably, this process was accomplished in a manner designed not only to punish but restore the offender. A public demonstration of inter-faith unity was made by IRO members, including a Sikh and Buddhist monk clad in saffron robes, who accompanied Nalla when he left the state courts. The remarks of District Judge Jasbendar Kaur ${ }^{201}$ were also restorationist: While the Imam should have been sensitive to Singapore's multi-religious context and not delivered sermons that might undermine racial and religious harmony, Nalla's admission of guilt, cooperation with the authorities, and demonstrated "strong sense of remorse" 202 was commended. The media publicized Nalla's active steps to contain the harm, which reflects the public ritual of apology and reconciliation. He made an open apology on March 31, 2017, before thirty Christian, Sikh, Taoist, Buddhist, and Hindu leaders at a meeting that he requested to be held at the Harmony in Diversity Gallery. ${ }^{203}$ He visited Rabbi Abergel at his synagogue on April 2, 2017, to tender a personal apology, ${ }^{204}$ again accompanied by IRO members in religious dress, demonstrating rapprochement.

The Imam's subsequent reconciliatory breakfast meeting with Law Minister K. Shanmugam at a mosque ${ }^{205}$ was widely publicized. The minister - who had stressed the government's zero tolerance policy towards violence-provoking religious preaching before Parliament-stated the deportation decision was taken "with some regret"; he lauded the Imam's sincere remorse and courage in meeting other faith leaders. ${ }^{206}$ The press published photos of a teary-eyed Imam and Minister breaking bread and hugging. ${ }^{207}$ MUIS and other Islamic bodies affirmed that there was "no room for discourse that promotes intolerance, enmity or violence against other communities," 208 while Muslim Affairs minister Yaacob Ibrahim stated that the rule of law would be applied without double standards to "protect all communities regardless of race or religion, from being denigrated." 209 The Imam clarified that his statement was from Indian custom-not the Quran-affirming the "priceless lesson" he took from this heuristic process, his belief there was no witch-hunt, as official action taken was "solely to preserve the sanctity of interfaith harmony." 210 Signaling restored equilibrium, the Imam mentioned the warm reception he received from the Anglican bishop and Jewish rabbi, who comforted him in stating "all mortal men make mistakes and that we must move forward consciously for the sake of social trust and religious cohesion." 211

The incident was capped by the Minister Yaacob's Facebook post thanking "our non-Muslim friends for accepting the apology," noting that gracious forgiveness reflected "the Singapore way" of upholding "mutual respect and harmony for our common good. ${ }^{212}$

\footnotetext{
${ }^{201}$ Public Prosecutor v. Nalla Mohamed, Brief Sentencing Remarks, MCN-900387-2017 (State Court); Imam Who Made Offense Remarks to Be Repatriated, TODAY, Apr. 3, 2017 [hereinafter Imam].

${ }^{202}$ Sentencing Remarks, supra note 201, at para. 5.

${ }^{203}$ Toh Yong Chuan, Imam Apologises for Insensitive Remarks, Clarifies That Remarks Were Not From Quran, STRAITS Times, Mar. 31, 2017.

${ }^{204}$ Seow Bei Yi, Imam Visits Synagogue to Apologize for Offensive Remarks, STRAITS Times, Apr. 3, 2017.

${ }^{205}$ Toh Yong Chuan, Minister Meets Imam Who Was Fined for Making Offensive Remarks and Will Be Heading Home, Straits Times, Apr. 5, 2017.

${ }^{206}$ Toh Yong Chuan, Shanmugam Appreciates Imams Sincere Apology, Straits Times, Apr. 6, 2017.

${ }^{207}$ Imam Has Shown Sincere Remorse, Regret: Shanmugam, ToDAY, Apr. 5, 2017.

${ }^{208}$ Nur Asyiqin Mohamad Salleh, Police Looking Into Conduct of All Involved in Imam Case, Straits Times, Mar. $4,2017$.

${ }^{209}$ Toh Yong Chuan, Yaacob: No Double Standards on Religious Harmony, STRAITs Times, Apr. 4, 2017.

${ }^{210}$ Toh, supra note 206.

${ }^{211}$ Toh, supra note 205.

${ }^{212}$ Imam, supra note 201.
} 


\section{Kingdom Invasion Conference}

The Muslim community reciprocated the forgiveness that other religious communities had extended Imam Nalla in forgiving remarks made by an American speaker, Lou Engle, at the Kingdom Invasion Conference hosted by Cornerstone Community Church in 2018.

A secular humanist, one Benjamin Lim, purchased a \$220 ticket to attend the conference; Lim wrote a hostile, christophobic article ${ }^{213}$ about it which was published on Rice Media online. It was provocatively entitled "Lou Engle: An American Threatens a Christian-Muslim Divide in Singapore" 214 and described Engle as making an "anti-Islam remark" at the conference where he apparently said: "I had a dream, where I will raise up the church all over Spain to push back a new modern Muslim movement," which a church spokesman described as relating to ISIS propaganda. Lim wrote that Engle had been in many controversies "for his homophobic and islamophobic" comments, such as urging his followers to pray for Muslims to have dreams of Jesus in Dearborn, Michigan, as "God wants to invade with His love Dearborn with dreams of Jesus." Engle was also the leader of an American pro-life movement that Lim found "contentious". The writer had "come to Kingdom Invasion to investigate whether Engle's speech would be as controversial as the ones that have cemented his reputation." He wrote that he could not believe his ears at what he heard, as “[i]sn't the mention of other faiths at a religious even sacrilegious in Singapore." He suggested that Engle's statement be interpreted to mean that "Islam is a threat to Christianity," and that Engle had expressed "fundamentalist extremist views." 215

In turn, the church filed a police report alleging that Lim's article constituted a "scurrilous attack" and was inflammatory in "stirring up religious tensions and promoting feelings of ill-will and hostility between Christians and Muslims." The article also had a "seditious tendency" and "denigrated the Christian faith." ${ }^{16}$ The article and police reports sparked investigations by the police and Home Affairs Ministry. ${ }^{217}$

Religious tensions were evidently stirred, so Cornerstone Pastor Yang Tuck Yoong issued a written apology and personally delivered this remark to Muslim leaders-including the Mufti -at a requested meeting: He regretted that Engle's remarks had "been the cause of considerable distress and misunderstanding, particularly among the Muslim community." 218 The Mufti and Muslim leaders accepted Pastor Yang's apology and declared their intent to "move on and look forward to a more constructive and healthy relationship." The Muslim Affairs Minister then gave the seal of ministerial approval through a Facebook post, stating that he appreciated Pastor Yang's apology and his taking responsibility for the invitation. Pastor Yang also promised not to invite Mr. Engle to speak in Singapore again, emphasizing that his church did not "condone any speech or actions that foster ill will between communities." 219

The media published photos of Pastor Yang and the Mufti warmly shaking hands. ${ }^{220}$ Shortly afterwards, former nominated MP Zulkifli Baharudin-Pastor Yang's university friend- organized a lunch between church and Muslim leaders at Ba'akwie Mosque, with both sides affirming

\footnotetext{
${ }^{213}$ Joseph Weiler coined this term in UN'EUROPA CRISTIANA: UN SAGGIO EsPLORATIVO (2003). It more narrowly referred to Europe's deliberate denial of its Christian roots in drafting the European Constitution, though it generally connotes an antiChristian bias. See George Weigel, The Cube And The Cathedral: Europe, America And Politics Without God 72-77 (2005).

${ }^{214}$ Benjamin Lim, Lou Engle: An American Threatens a Christian-Muslim Divide in Singapore, RICE MEDIA, Mar. 5, 2018.

${ }^{215} \mathrm{Id}$.

${ }^{216}$ Jeanette Tan, Church in S'pore Makes Police Report Against Rice Media for 'Scurrilous Attack' in Article, MOTHERSHIP, Mar. 27, 2017.

${ }^{217} I d$. To my knowledge, the matter has been dropped and no action taken.

${ }^{218}$ Justin Ong, Singapore Pastor Apologises to Muslim Leaders for US Preacher's Alleged Statements on Islam, CHANNELNEWS Asia, Apr. 4, 2018.

${ }^{219} \mathrm{Id}$.

${ }^{220}$ Zhaki Abdullah, Police Ask US Preacher to Return for Interview, STRAITs TimES, Apr. 5, 2018.
} 
that "these sorts of things can be easily resolved ... by meeting together." The attending dignitaries included President Halimah's husband. Mr. Baharudin realistically observed that it was not possible to completely avoid these sorts of disputes, and that the "only guarantee" was that of "goodwill" which "starts from personal relationships," as his actions demonstrated. Showing moral leadership, he demonstrated a relational approach in urging religious communities to welcome those "who have made mistakes, with love, with care, as a brother," as "Singaporeans should be like that, and Muslims in Singapore are capable of that." ${ }^{21}$ The NCCS also issued a public statement affirming the "measured response" of MUIS and their "gracious acceptance" of Pastor Yang's apology as actions worthy of emulation. They praised the "magnanimity which bodes well for inter-religious harmony in our nation" and considered it "marvelous" that where "unintended hurts" are caused, religious leaders "can graciously and maturely handle the matter and keep unhappiness from deepening or spreading." 222

\section{Analysis and Observation on Religious Disharmony Incidents}

Religious disharmony disputes implicate entire communities. CCR plays the functional role that traditional religion has played in times past in cohering society. A harmony-centric CCR which promotes social norms and encourages conciliatory methods of dispute resolution has generated an emergent public ritual over time whose aim is to preserve social cohesion. This ritual involves the offending party extending an apology and taking measures to avoid repetition; the offended party is expected to graciously accept, not churlishly, spurn the apology. This ritual provides a publicly shared moment for the mutual reaffirmation and recommitment to shared values like working together towards religious harmony, which attracts ministerial level approval of this settlement which disposes of the case. These rituals compose a "unique blend of emotion, physical performance and communicative activity." 223

The government that has the final say in preserving the public order has chosen to ignore actors seeking to disrupt this settlement by perpetuating the dispute or continuing to demonize the repentant offending party and pour fuel on the embers of a dying fire; such vindictive attacks can cross the line and become persecutory. Attacks on a religious leader may provoke retaliatory countermeasures from his religious community, exacerbating social tensions and rendering religious harmony elusive. Conflict entrepreneurs who seek to incite hostility towards religious group A by raising the ire of religious group B-because they see group A's values as an obstacle to their political agenda - may abuse the ideal of religious harmony by weaponizing it to whip up social disapprobation, intimidating group A into silence. This exploitation of religious sensitivities for political gain is evident in the Rice Media article which essentially equated prayer for Muslims in America as a negative targeting of Muslims in Singapore. Because Muslims believe that Jesus or Isa is a prophet, one might see a call for God's love to invade them as a prayer for divine blessing motivated by love, rather than something malicious. People will always disagree on such matters, but friends give the benefit of the doubt, while antagonists seek to cast aspersions to make political capital against the disliked religious group. ${ }^{224}$ This too may cause social disharmony, as relationalism cannot coexist with practitioners of mischievous or malevolent tactics who thrive on agonistic social relations.

\footnotetext{
${ }^{221}$ Low De Wei, Regular Meetings Can Resolve Religious Controversies Say Muslim and Christian Community Leaders, Straits Times, Apr. 13, 2018.

${ }^{222}$ Justin Ong, Singapore Churches Must Exercise Due Diligence, When Inviting Foreign Preachers, Says National Council, ChannelNews Asia, Apr. 5, 2018.

${ }^{223}$ Andrew Cappel, Bringing Cultural Practice into Law: Ritual and Social Norms Jurisprudence, 43 SANTA CLARA L. REV. 389, 395 (2003).

${ }^{224}$ The Rice Media article revealed its anti-Christian bias, in speaking of "the growing influence of the Christian right in Singapore's society," as this opposes the homosexualism agenda that Lim supports. Lim, supra note 214.
} 
These reconciliation rituals stir emotions; in motivating reciprocal compliance, it shapes behavior in future disputes. CCR is thus developed through practice, such as the duty to apologize and to forgive as a means of operationalizing commitment to religious harmony.

Mr. Baharudin's comments speak of friendship, which entails maintaining a continuing relationship rather than shunning a person. Harmony is supported by friendly relationships or friendships, which have developed between leaders of different religious groups. In 2010, a church deacon and Taoist leader resolved a conflict, publicly demonstrating this by singing together at a concert which the Prime Minister graced. This demonstration signifies approval by political leaders of these conciliatory efforts. This same duo reprised their performance at a 2015 inter-faith concert which the Prime Minister also attended. ${ }^{225}$ Optics - in the form of media coverage-are important, as this reconciliation ritual is designed to restore harmonious equilibrium and signal unity as well as the implicit approval of an important personage in attendance. Both community actors and the government are involved in this ritual, which seeks to realize the substantive goals of CCR within a constitutional order that protects and qualifies religious freedom.

Rituals are expressions of the normative commitments of a political community. It may be argued that a hortatory soft law norm as part of this reconciliation ritual has developed as a response to disharmony incidents where repentance is met with forgiveness and restoring the offending party to good standing. This argument is bolstered by ministerial affirmations of forgiveness being described as "the Singapore Way," 226 supported by a harmony chorus sung approvingly by religious leaders and other stakeholders. This process facilitates an environment where social trust and strong relational bonds can be cultivated through dialogue and diplomacy, reflecting the method and objective of relational constitutionalism.

\section{Concluding Reflections on Solidarity in Diversity: I, We, and Them}

Beyond rights and institutions, the political community needs a sense of conviction that we the people are bound to a shared enterprise or "common historical project," 227 that transcends "enduring fault lines" 228 of race and religion. The CCR seeks to erase the us versus them mentality. Carl Schmitt noted the "specifically political distinction . . . is that between friend and enemy";229 the task of creating friendly relations is key to realizing solidarity in diversity.

Like religion, political ideologies may assume an "idolatrous character, and like all idols, are unwilling to share power with others." ${ }^{230}$ The Singapore CCR is minimalist in not coercing belief in substantive values, and procedural in its primary concern to secure a framework for pacific coexistence between religious group; insofar as Singapore is "an oasis of religious peace" 231 in a troubled world, the CCR has enjoyed some success as a civilizing force in nurturing citizen responsibilities.

Civil religions may be spontaneous, organic products or some of "deliberate design and manipulation," a tool to enforce ideology. ${ }^{232}$ Singapore's CCR is state-directed and secular, a basis

\footnotetext{
${ }^{225}$ Song of Friendship, STRAits Times, Dec. 4, 2010; Jasmine Osada \& Lim Yan Liang, Inter-faith Concert Gets Strong Show of Support, STRAits Times, July 7, 2015.

226“I thank our non-Muslim friends for accepting the apology. Their willingness to forgive reflects the Singapore way, where we uphold mutual respect and harmony for our common good." Yaacob Ibrahim, FACEBOoK (Apr. 3 2017), https://www. facebook.com/yaacobibrahim/posts/this-incident-involving-imam-nalla-of-jamae-chulia-mosque-has-been-a-trying-one-/ 1474940742540429.

${ }^{227}$ Paul W. Kahn, A Civil Religion of Human Rights, in Civil Religion, Human Rights and InTERnational Relations: Connecting People Across Cultures and Traditions 42, 57 (Helle Porsdam ed., 2012).

${ }^{228}$ Prime Minister Lee Hsien Loong, supra note 3.

${ }^{229}$ Carl Schmitt, The Concept OF the Political 26 (G. Schwab trans., 2007).

${ }^{230}$ David T. Koyzis, What Would Kuyper Do? Idolatry and the Limits of Pluralism, Finst Things, Jan. $23,2015$.

${ }^{231}$ Shanmugam, supra note 109.

${ }^{232}$ Marcela Cristi, From Civil to Political Religion: The Intersection of Culture, Religion and Politics 33 (2001).
} 
for the justification of actions, although consensus-building efforts are made to gain broad support for its tenets. In an era of ethnic chauvinism and exclusivist ideologies that "deepen communal and religious fault lines," the government is determined that "here in Singapore, we will resist this tide." 233 This sentiment is in pursuit of the chosen "nobler dream" to have a "multi-racial, multireligious Singapore,"234 anchored by the CCR commitment to racial and religious harmony.

\footnotetext{
${ }^{233}$ Prime Minister Lee Hsien Loong, Transcript, Swearing in Ceremony for President Halimah Yacob (Sept. 14 2017), https://www.pmo.gov.sg/newsroom/pm-lee-hsien-loong-swearing-ceremony-president-halimah-yacob. ${ }^{234} I d$.
}

Cite this article: Thio L (2019). Irreducible Plurality, Indivisible Unity: Singapore Relational Constitutionalism and Cultivating Harmony Through Constructing a Constitutional Civil Religion. German Law Journal 20, 1007-1034. https:// doi.org/10.1017/glj.2019.75 